\title{
TOPLUMSAL DEĞişiM
}

\section{RAPORLARI}

Gençlik ve Sosyal Katılım

Editör: Zübeyir NişANCI 
TOPLUMSAL DEĞ Iş I M R A P O RLAR I

Gençlik Ve sosyal katilim

Dr. Öğretim Üyesi Zübeyir NişANCI

tdde

(ㄱ) 
Koordinatör

Zübeyir Nişancı, Dr. Öğretim Üyesi

Marmara Üniversitesi

Araştırmacılar

Atakan Batur

Ekrem Çeçen

Elif Altın

Öznur Altındal

Rabia Özkan

Sehnaz Fındı

\section{Tasarım ve Uygulama}

fibulo

Yayın Türü

Türkçe E-Rapor

İletisim

Insan ve Medeniyet Hareketi

Bahariye Mevlevihanesi, Eyüp Merkez Mahallesi, Silahtarağa Cad. No: 12 Eyüp, İstanbul

Telefon: +90 (212) 501-3171 Web: http://toplumsaldegisim.com

Elektronik posta: admin@toplumsaldegisim.con 
...........

….......

ค..........

$\cdots \cdots \cdots \cdots$

\section{İçindekiler}

Yazarın Özgeçmişi $\quad 08$

Sunuş

Özet

Giriş

Gençler Arasında Sosyal Katılımın Dönüșümü

Sosyal Medya Katılımı

Sosyal Medya Kanalları

Sosyal Medya Etkileyicileri (Influencer)

Anonim Katılım

Dijital Katılım

Sosyal Medya Savunuculuğu

Fotojenik Katılım

Dijital Oyun Katılımı

Dijital Medya Platformu Katılımı

Video Konferans Katılımı

\section{Devamlılık ve Motivasyon}

Liderlik

Sosyal Sermaye Olarak Sivil Katılım

Sosyal Sermaye

Sosyal Sermaye Türleri

Katılımı Zorlaștıran Faktörler

Güven

Gençliğin Sosyal Katılımında Sivil Toplum

Kuruluşlarına Güven

Devlet Kurumlarının STK Kaygıları

STK'ların Kurumsal İmajı ve Gençlerin Sosyal Katılımı

Devlet Destekli Sivil Toplum Kuruluşları

Aile Beklentileri ve Gençlerin Sosyal Katılımı Üzerine

Arkadaş Baskısının Gençlerin Sosyal Katılımına Etkisi (Peer Pressure)

Sonuç ve Öneriler

Kaynakça 


\section{Yazarın Özgeçmişi}

Zübeyir Nişancı, Marmara Üniversitesi'nde öğretim üyesidir. Boğaziçi Üniversitesi Sosyoloji bölümünde lisans, Hartford International University bünyesinde din araştırmaları alanında yüksek lisans derecesini tamamladı. Yüksek lisans eğitimi sırasında Hartford Institute Religion Research'da (Hartford Din Araştırmaları Enstitüsü) araştırma projelerinde çalıştı. Doktora eğitimini de Loyola University Chicago Sosyoloji bölümünde tamamladı. 2009-2014 yılları arasinda Loyola University Chicago'da okutman olarak dersler verdi. Aynı okulda 2011 ve 2013 yılları arasında İstatistik Danışmanı olarak çalıştı. 2015 ve 2019 yılları arasında İstanbul Şehir Üniversitesi sosyoloji bölümünde öğretim üyesi olarak ders verdi. Nicel Araştırma Metodları, Gençlik Araştırmaları, Din Sosyolojisi, Sivil ve Sosyal Katılım, Sosyal Eşitsizlikler, Göçmenlik ve Küreselleşme başlıca ilgilendiği konular arasındadır.

\section{Sunuş}

Türkiye'de yaşayan gençlerin sosyal ve sivil katılım dinamiklerini inceleyen bu rapor, Toplumsal Değişim Enstitüsü çatısı altında 2020 ve 2021 yıllarında ekip olarak yürüttüğümüz atölye çerçevesinde yapılmış kapsamlı bir çalışmanın ardından ortaya çıkmıştır.

Atölye çalışmamızın ana hedeflerinden biri Türkiye genelinde başta gönüllülük ve STK faaliyetleri olmak üzere gençlerin sosyal ve sivil katılım türlerini ve seviyelerini belirlemekti. Gençlerin sosyal katılımını kısıtlayan faktörlerin tespit edilmesi ise bir diğer ana hedefimizdi. Bu amaçlar doğrultusunda önce ekip olarak ilgili literatür taraması, okuma ve tartışma eşliğinde araştırma kurgumuzu belirledik. Bu kapsamda öncelikli olarak farklı STK'larda aktif olarak yer alan gençler ile yüz yüze ve çevrim içi odak grup mülakatları yaptık. Daha sonra atölyeye katılan genç araştırmacılar bireysel olarak kendi arkadaş ve okul çevrelerinden ulaşabildikleri farklı sosyoekonomik profillere sahip gençlerle konu ile ilgili birebir mülakatlar yaptılar. Neticede bu bulguları öne çıkan başlıklar altında rapora dönüștürdük. Bu bulgulardan hareketle de rapor içerisinde gençlerin sosyal katılımlarını desteklemeye yönelik uygulama önerilerini paylaştık.

Rapor, halen yüksek lisans ve doktora eğitimlerine devam eden genç araştırmacılardan Atakan Batur, Ekrem Çeçen, Elif Altın, Öznur Altındal, Rabia Özkan ve Şehnaz Findık'ın yoğun emek ve katkıları ile tamamlandı. Bu yönüyle raporun sadece Türkiye’deki gençler arasındaki sosyal ve sivil katılım araştırmalarına katkı yapmakla kalmayıp alanda araştırma ve raporlama tecrübesi kazanan araştırmacılar yetiştirilmesi noktasında da doğrudan katkı sağlamış olduğuna inaniyoruz.

Bu doğrultuda bize bu çalışma imkânını tanıyan Toplumsal Değişim Enstitüsü'ne, enstitü idaresi adına bizlere verdiği her türlü maddi ve manevi destekleri dolayısıyla Sayın Haluk Nas'a ve atölye süresince sabırla ve özveriyle çalışmaların koordinasyonunu noktasında destek olan Melike Halide Ekinci'ye teşekkürü borç biliyoruz.

Dr. Öğretim Üyesi Zübeyir Nişancı 


\section{Özet}

$\mathrm{Bu}$ rapor Türkiye genelinde gençlerin sosyal ve sivil katılım düzeylerini belirleyen ve kısıtlayan faktörleri nitel araştırma yöntemleri kullanılarak elde edilen bulgular üzerinden incelemektedir. Araştırma sorularını ve yöntemini proje ekibimizin yaptığ 1 akademik literatür taramasina dayanarak oluşturduğumuz bu araştırma, sosyal katılım ile ilgili ve tecrübeleri olduğunu düşündüğümüz genç yaştaki STK yöneticileri ve aktif olarak sivil ve sosyal katılımı devam eden gençler ile pandemi kuralların bağlı kalarak, yüze yüze veya çevrim içi mülakatlar yaptık. Ayrıca proje ekibindeki araştırmacı katılımcılarımız kendi ulaşabildikleri bağlantılar üzerinden benzer profildeki gençler ile birebir mülakatlar gerçekleştirdiler. Gençlerin sosyal ve sivil katılımlarının azalmaktan ziyade çok hızlı bir şekilde değiştiği ve çeşitlendiği ve bu dönüşümün daha çok dijital katılım ile olduğu raporun öne çıkan vurgularından biridir. Bunun yanında gençlerin bireysel beklentileri, aile ve arkadaş ilişkileri yanında Türkiye'de son yıllarda yaşanan sosyal ve siyasal olay ve dönüşümlerin gençlerin sivil ve sosyal katılımlarına etkisi de ek başlıklar olarak raporda sunulmaktadır.

\section{Giriş}

Toplumsal Değişim Enstitüsü (TDE) bünyesinde ekip çalışması hâlinde hazırlanan bu rapor Türkiye'de gençlerin sosyal ve sivil katılımındaki dönüşümleri ve gençlerin katılımını kısıtlayan faktörleri ayrı ayrı başlıklar hâlinde incelemektedir. Ayrıca rapor, sonuç bölümünde gençliğin sosyal katılımı destekleme ve geliştirmeye yönelik atılabilecek adımları ilgili uygulayıcı ve politika yapıcıların dikkatine sunmaktadır.

$\mathrm{Bu}$ raporun temelini oluşturan araştırmada ilgili akademik literatür taramasına ek olarak proje ekibimiz tarafindan yapılan mülakatların bulguları da kullanıldı. Ekip olarak gençlerin sosyal katılımıyla ilgili, tecrübeleri olduğunu düşündüğümüz yine genç yaştaki STK yöneticileriyle ve aktif olarak sivil ve sosyal katılımı devam eden gençlerle pandemi şartlarına bağlı olarak yüz yüze veya çevrim içi mülakatlar yapıldı. Ayrıca proje ekibindeki araştırmacı katılımcılar kendi ulaşabildikleri bağlantılar üzerinden benzer profildeki gençlerle birebir mülakatlar gerçekleştirdi. Proje rapor metni bu mülakatların bulguları da detaylı olarak yorumlandıktan sonra yazıldı.

Projenin ana odağında gençlerin sivil ve sosyal katılımlarının genel durumunu betimlemek ve eğer bu alanlarda bir değişim gözlemleniyorsa bu değişimin yönünü anlamaya çalışmak yer almaktadır. Her ne kadar son yıllarda gençlerin genellikle STK katılımlarını ve gönüllülük faaliyetlerini içeren sivil katılımında bir azalmanın söz konusu olduğu kanaati yaygın olsa da mevcut proje bulguları gençlerin sivil ve sosyal katılımının artması veya azalması meselesinden daha önemli olanın gençlerin sivil ve sosyal katılımlarının yönünün tayin edilmesi olduğunu göstermektedir. $\mathrm{Bu}$ nedenle bu proje metni de öncelikli olarak gençlerin sosyal katılımındaki yeni formları tespit edip betimleyerek başlamaktadır. 
$\mathrm{Bu}$ raporda bahsi geçen yeni katılım türlerinin her biri ana hatları ile ayrı ayrı başlıklar altında ele alınmıştır. İkinci bölümde gençlerin sosyal ve sivil katılımlarını kısıtlayan faktörler ayrı ayrı başlıklar hâlinde incelenmiştir. Sonuç bölümünde ise proje bulgularından hareketle özellikle gençlerle çalışan STK'ları ve ilgili diğer politika yapıcılarını bilgilendirmeye yönelik olarak politika önerileri paylaşılmıştır.

\section{Gençler Arasında Sosyal Katılımın Dönüşümü}

\subsection{Sosyal Medya Katılımı}

Bir katılım formu olarak medya araçlarının kullanılması özellikle de teknolojik gelişmeler vasıtası ile etkinliğini artırmıştır. Televizyon, gazete vb. geleneksel medyanın sağladığı imkânlar nispeten pasif bir katılım formunu öngörmekteyken özellikle internet kullanımının yoğunlaştığı son on yılda alternatif medyanın sunduğu imkânlar daha dikkat çekici bir hâl almaya başlamıştır. Yeni medya olarak da nitelendirilen bu süreç internetin kendi içindeki değişim ve dönüşümüyle bağlantılı ele alınmaktadır. Web 2.0 Dönemi diye isimlendirilen bu dönemde kullanıcılar, dinleyici/ izleyici/okur olmanın beraberinde kendi içerik ve paylaşımlarını sesli, görüntülü, canlı vb. olmak üzere birçok formatta sunma imkânı elde ederek bir anlamda mikro yayıncı olabilme firsatı elde etmektedirler (Yavaşçalı ve Uğurhan, 2019).

İnternet ortamının sağlamış olduğu zaman ve mekândan soyutlanmış, objektif, hızlı ve interaktif katılıma imkân sağlayan alternatif medya yolları arasında en dikkat çekenlerden biri ise sosyal medya araçlarıdır. 2015 yılı itibariyle internet kullanan kişi sayısı dünyada 3 milyarı aşmışken 2.1 milyarının sosyal medya hesabı vardır (Internet Stats and Facebook Usage in Europe Statistics, 2015). Bu durum kişilerin birçok boyutuyla sosyal medyayı katılım aracı olarak tercih ettiğini göstermektedir. Sosyal medyanın net bir tanımını yapmak her ne kadar kolay olmasa da içeriğinin kullanıcılar tarafından üretildiği, paylaşıldığı çevrim içi platformlara verilen genel isim olarak değerlendirilebilir (Ying, 2012). Bu tanımdan hareket edildiğinde sosyal medyada en önemli noktanın kişilerin kendi aktif üretimine bağlı olduğunu ve kullanıcılarının doğrudan katılımına ortam sağladığını söylemek mümkündür.

Sosyal bilimlerin perspektifinden karşılıklı etkileme ve etkilenme ile sosyal durumların ortaya çıktığı (Metin, 2016) göz önüne alındığında, gelişen durumlara hızlı bir şekilde tepki oluşturulabilmesi, daha geniş bağlamlarla iletişimi sağlaması ve kişilerin kendi içerikleri ile çevrelerinde etki oluşturabilmelerine alternatif ve öznel bir alan sunması bakımından sosyal medya, sosyal etkileşimin en ulaşılabilir formlarından biri olarak karşımıza çıkmaktadır. Nitekim yapılan mülakatlarda bir katılımcı şunları söylemiştir:

"Katıldığım etkinlikleri sosyal medyada paylastığımda kendimi övünüyor gibi hissetsem de bu etkinliklere iliş̧kin sorular aldığımda bunun yayılması için bir araç olduğunu fark ettim. Bu cihetiyle faydasımın daha çok olduğunu düsündü̈̆̈̈̈mden katıldiğım etkinlikleri sosyal medya hesaplarımdan paylaşmaya karar verdim." (Öğrenci, Kiz, 23)

Sosyal etkinlikler ve bu etkinliklere katılım noktasında kişiler kendilerine ait hesaplarında bu içeriklerin paylaşımı vasıtasıyla çevreleriyle etkili ve hızlı bir etkileşim kurma imkânı ediniyorlar. Bu da netice itibariyle sosyal medya aracılığı ile kurulan iletişimin hem gerçek hayatta hem de sosyal medya dünyasında katılımı artırdığını göstermektedir.

Bununla birlikte sosyal medyanın sağlamış olduğu geniş enformasyon ağı, özelliklegençlerin farklı eğilimlerle karşılaşmalarını sağlamaktadır. Tanışılan yeni akımlarda kendilerine uygun buldukları enformasyon ağıyla gençlerin entegrasyon süreci yaşadığı da söylenebilir. Sosyal 
medyanın gençlerin ilgi ve temayüllerini keşfetmelerini sağlayarak bu anlamda etkinliğini artırdığını belirten bir katılımcı sosyal medya vasıtası ile gençlerin psikososyal olaylardan elde ettikleri faydanın arttı̆̆ına işaret etmiştir (Öğrenci, Kız, 23). Bu faydaların başında medyanın bir katılım vasıtası olarak karşımıza çıkmasının yanında gençlerin kendi alanlarına karşı ilgilerini geliştirdiklerini de belirten katılımcılar, sosyal medyanın gençlerin artık daha çok yöneldiği bir araç olduğunu söylemişlerdir. Ayrıca katılımcıların altını çizdiği hususlardan bir tanesi de gençlerin bu yönelişinin fark edilerek kendilerine uygun, gelişime ve değişime açık projelerin yaygınlaştırılmasının talebi üzerinedir (Öğrenci, Erkek, 22). Bütün bunlar birlikte değerlendirildiğinde gençlerin kendi alanları başta olmak üzere diğger disiplinler ve sosyal çevrelerle tanışmak, derin ilgi sahaları oluşturarak etkinlik kurmak amacıyla sosyal medyanın aktif kullanıcıları olduğu belirtilebilir.

Yine genç nüfus arasında siyasi olaylara karşı takınılan apolitik tavırla birlikte düşünüldüğünde gençler arasında önemli bir kesimin sosyal medyayı siyasi olayları takip etmek, bu bağlamdaki tartışmalara katılmak için kullanıyor olmaları da altı çizilmesi gereken hususlardan biridir (Gür ve Bahçeci, 2014). Aşağıda incelenecek olan sivil hareketler ve hak savunuculuğu gibi güncel hayatın sorunlarına doğrudan katılımı sağlayan meselelerin yanında genç kitlenin sosyal medyayı siyasi perspektif dâhilinde kullanıyor olmaları pratik kaygılardan azade, kendine has bir siyasi katılım formunu oluşturduğunu göstermektedir. Oy kullanmak haricinde siyasi eylemlerde çok fazla rol almayan genç nüfusun sosyal medya üzerinden siyasi alana bilgi almak amaçlı dahi olsa entegre olduğu söylenebilir (Görgülü, 2018). Ayrıca siyasal toplumsallaşma süreci bakımından sosyal medya kanalları, pratik hayata nazaran daha demokratik, özgürlükçü ve çoğulcu bir ortam sağlayarak katılımcılara gündelik hayatta bulamayacakları bir imkân sağlamaktadır. Bununla birlikte bu çoğulcu ortamın siyasi katılım üzerinde örtük olumsuzlukları olabileceğini de belirtmekte fayda vardır. Çünkü bu ortamın gerektirdiği diyalog ve hoşgörü ortamı katılımcıların kendi kimliklerini açıklamaktan kaçınarak farklı bir görünüm altına sığınmalarına da sebep olabilmektedir (Metin, 2016). Bu çekincenin büyük çerçevede sosyal medya katılımının temel bir sorunu olduğunu belirtmek gerekir. Her ne kadar sanal ağlar artık gerçek hayatın vazgeçilmez bir unsuru olarak eklemlenmiş olsa bile bir bakıma reel dünya gerçekliğinden farklı bir boyuta tekabül etmektedirler. Bu nedenle sosyal medya üzerinden karşılaşılan katılım formlarında katılımcıların kendilerini oldukları gibi ifade etmemeleri karşılaşılması muhtemel durumlardandır. Sosyal medyanın gerçek olmayan profiller oluşturmaya imkân sağlayan dünyası bu bağlamda altı çizilmesi gereken hususlardan biridir. Bununla birlikte belirtmek gerekir ki sosyal medyada aktif paylaşım yapan bir katılımcı gerçek ve doğal olanın yansıtıldığı içeriklerin daha çok etkileşim aldığını söylemiştir (Influencer, Kız, 25). Buradan hareketle sosyal medya kanalları ile oluşan katılımda her ne kadar sahtelik riski bulunsa da katılımcllığın etkinliği ve devamlılığında doğallığın daha önemli rol oynadığını söylemek mümkündür.

İnternetin yaygın kullanımı ve sosyal medyanın yoğun şekilde tercih edilmesi insanların gerçek mekânlardan ve gerçek ilişkilerden soyutlanarak yalnızlığa itildiğine (Karakoç ve Taydaş, 2013) dair eleştirileri beraberinde getirmiştir. Fakat yukarıda açıklanmaya çalışılan husus bu iddiaların bir anlamda doğru olmadığıdır. Çünkü sosyal medya da bir anlamda kendi paralel evrenini oluşturmuş ve katılımcılarına klasik çerçeveye sığmayan yeni bir katılım şekli sunmuştur. Bu katılımın, özellikle de bütün katılımcılara sunduğu aktif pozisyon sayesinde klasik olmayan fakat gerçek bir katılım olduğu söylenebilir. Bilhassa da gençlerin sosyal medya kullanıcılarının çoğunluğunu oluşturduğu göz önüne alındığında gençler ve toplum arasındaki bütünleşme bakımından bu durum 
dikkate alınmalıdır. Hem gençlerin sosyal hayata dokunabilmesi hem de sosyal organizasyonların gençlere ulaşabilmesi bakımından sosyal medya önemli bir imkân kapısı olarak hayatımızdaki yerini almıştır.

\subsubsection{Sosyal Medya Kanalları}

Sosyal medyanın doğrudan bir tanımını yapmak belirttiğimiz gibi çok kolay değildir. Bununla beraber bir internet platformunu sosyal medya olarak değerlendirebilmek için literatürde birtakım kriterler belirlenmiştir. Bir sosyal medya kanalından bahsedebilmek için özellikle şu kriterlerin varlığı yaygın bir şekilde aranmaktadır (Tutkun Ünal, 2020):

\section{Katılım \\ Açıklık \\ Karşılıklı konuşma \\ Topluluk \\ Bağlantısallık}

Fakat sosyal medya kanallarının kendi içinde farklılaşması bu özelliklerin her birinin değişik yoğunluklarda görünüm kazanmasıyla söz konusu olmaktadır. Bu bağlamda bazı sosyal medya kanallarının özelliklerine değinmek, bu kanallar vasıtasıyla oluşan katılımı anlamak bakımından önem arz etmektedir. Fakat sosyal medya kanallarının kendi içinde farklılaşması bu özelliklerin her birinin değişik yoğunluklarda görünüm kazanmasıyla söz konusu olmaktadır. Bu bağlamda bazı sosyal medya kanallarının özelliklerine değinmek, bu kanallar vasıtasıyla oluşan katılımı anlamak bakımından önem arz etmektedir.

\section{Wikiler}

Katılımcıların belirli hususlarda bilgi paylaşımı yaptıkları, bu paylaşımların belirli sistematiğini oluşturdukları ve birçok katılımcı tarafından zenginleştirilmeye açık sosyal medya kanalları olan wikiler sosyal medyanın en eski kullanım formlarından biridir. Wikiler, kişilerin kendi bildiklerini ("what i know is” kalıbının baş harfleri ile isimlendirilmiştir) çevrim içi bir platformda sunarak herhangi bir merkezi denetime tâbi olmayan, nispeten özgür ve bir anlamda da denetim dışı bir enformasyon havuzu oluşturmalarını sağlamaktadır (Köse, 2008). Küresel bağlamda en yaygın kullanılan platform olarak Wikipedia örnek gösterilebilir. Ülkemizde ise Ekşi Sözlük, bunun en bilinen örneği olarak karşımıza çıkmaktadır.

Wikiler interaktif bir katılım formu oluşturmamakla birlikte katılımcısına belli bir konu üzerine kendi dağarcığını aktarma imkânı sunması bakımından önemlidir. Çünkü bilgi paylaşımıyla birlikte katılımcılar o konu üzerindeki kendi duygu ve düşüncelerini de yansıtma imkânı bulmaktadır. Ülkemizde bu vb. platformların zaman zaman belirli ideolojilerle bağdaştırılması da bu durumun yansımasıdır. Aynı şekilde üniversite öğrencilerinin kendi üniversiteleri özelinde açtıkları sözlük vb. platformlar da bilgi paylaşımından ziyade öğrencilerin üniversitede var olan süreçlere müdahil olması anlamında rol oynamaktadır.

Yine doğrudan içerik üreticisi olarak rol oynamayan birçok kullanıcı bilgi edinmenin yanında açık veya örtülü bir şekilde bu yönlendirmelere maruz kalmakta ve bir etkileşim sürecinin edilgen aktörü olmaktadır. Bunların hepsi birlikte değerlendirildiğinde interaktifliğin en sığ olduğu bu kanalda dahi derin bir etkileşim ve katılım sürecinin oluştuğundan bahsedilebilir. 


\section{Bloglar}

Kişisel web sitesi niteliği taşıyan bloglar, kullanıcısına kendi uzmanlık veya ilgi alanına dair paylaşımlar üretme ve bunu internet ortamında teknik bilgiye minimum derecede ihtiyaç duyarak paylaşma imkânı sunan platformlardır. Diğer sosyal medya ağlarına nispeten yine karşılıklı etkileşimin düşük olduğu bloglarda, blog sahibinin izniyle paylaşımlara yorum yapılması ve okuyucu ile içerik üreticisi arasındaki ilişkinin sağlanması mümkün olmaktadır.

Bloglara bir katılım formu olarak baktığımızda kişilerin kendi birikimlerini sunma ve zenginleştirme noktasında önemli rol oynadığını söylenebilir. Herhangi bir web site altyapı sistemine ihtiyaç duymaksızın oluşturulma imkânı, kullanıcı kitlesinin genele hitap etmesini sağlamaktadır. Gerek bilgi gerek ilgi bağlamında kullanıcılar bu platformda katılım imkânı buluyorlar. Tarayıcı aramalarında bu vb. sitelerin çıkması alana ilgili kişilerin birbiriyle etkileşim kurmasını sağlamaktadır. Nitekim katılımcılardan birinin belirttiği gibi gençler kendi alanlarına dair daha derin ilgi alanlarını sosyal medya vasıtası ile zenginleştirmektedirler (Öğrenci, Kız, 23). Ayrıca yukarıda belirtilen yorum yapma gibi özelliklerin eklenip kullanılmasıyla içerik üreticisi ve okuyucusu bir iletişim ağını oluşturmakta ve bir anlamda sosyal bağlantılar kurulmasına kapı aralamaktadır.

Yapısal açıdan bloglara benzeyen ama bir konuya ilişkin üretilmiş bir içerikten ziyade güncel meseleler hakkında anlık ve hızlı bağlantı kurmayı sağlayan sosyal medya araçları ise mikrobloglardır. Mikroblogların kısıtlı paylaşıma imkân sunması bir dezavantaj olarak görülebilir. Ancak mikroblog paylaşımlarının anında ve daha hızlı tüketilmesini sağlayan bu yönü, anlık ve güncel olaylara ilişkin aktif katılımı yoğunlaştıran bir husus olarak ortaya çıkar.Mikroblogların en yaygın kullanılanı ise Twitter'dir.

\section{Twitter}

Twitter bir mikroblog olma özelliğinden ötürü anlık paylaşımların kısıtlı karakterlerle sunulduğu bir sosyal medya kanalıdır. Hem küresel olarak hem de ülkemizde en çok tercih edilen sosyal medya araçlarından biridir. Kullanıcılarına 280 karakterle sınırlı "tweet" atma imkânı veren Twitter, bir katılım formu olarak sürekli bu yönünü geliştirici güncellemeleryapmaktadır.Örneğin kullanıcıların beğendikleri veya kendi takipçilerinin görmelerini istedikleri bir paylaşımı "retweet" yapma özelliğine ek olarak son dönemde gelen güncelleme ile söz konusu tweeti bir yorum eşliğinde "quote" etme yani alıntılama imkânı sunmuştur. Bu özellik katılımcıların birbirleri ile etkileşimini yoğunlaştırmıştır. Yine bir tweete yorum yapma yolu olan "mention" da benzer bir işlevi görmektedir.

Son günlerde popülerlik kazanan sesli paylaşıma imkân sunan "clubhouse" uygulamasına benzer bir özelliği de bünyesine ekleyen Twitter sesli tweetten sonra bazı katılımcıların bir araya gelip doğrudan iletişim kurabildikleri özelliklerini de geliştirmektedir.

Bu yönde katılım sürecinde aktif rol oynayan Twitter'da bazı kullanıcılar paylaşım yapmak bakımından aktif bir katılım göstermeseler de sosyal çevrelerini takip ederek bir anlamda "haberdar" olmak maksadıyla Twitter'ı yoğun kullanmaktadırlar. Her ne kadar kendileri doğrudan bir içerik paylaşımcısı olmasalar da bir katılım sürecinin parçası oldukları açıktır. Katılımcılardan biri Twitter'ın gençlerin yoğun kullandığı bir platform olmasından ötürü gençlere ulaşmak bakımından nitelikli bir araç olduğunu belirtmiştir (Öğrenci, Erkek, 22). Twitter'ın günceli takip etmedeki hızlı rolü sayesinde katılımcılar gündelik, toplumsal, siyasi olaylarda hızlı bir şekilde kamuoyu oluşturabilmektedirler. Bu durum da yine katılımcıların sosyal hayatla bağlantı kurmaları ve kendi görüşlerini sunmaları bağlamında önem taşımaktadır. 


\section{Sosyal Ağlar}

Sosyal ağlar, internet kullanıcılarının aktif katılımlarını en içkin özellik olarak barındıran sosyal medya araçlarıdır. Kişilerin kendi oluşturdukları profillerde görüntü, ses, video vb. içerikleri çevreleri ile paylaşma imkânı bulduğu sosyal ağlar günümüzde özellikle de gençlerin en önemli sosyalleşme araçlarından biri olarak karşımıza çıkar (Ying, 2012). Dünya nüfusunun üçte ikisinin sosyal ağlar üzerinde profili olduğu (Genç, 2015) dikkate alındığında bu ağların ne kadar yaygın kullanıldığı anlaşılacaktır. Her ne kadar Twitter için belirtilen içerik paylaşmadan yalnızca takipçi veya arkadaş olma özelliği bu kanallarda da karşımıza çıksa da kullanıcıların bu ağlar üzerinden sanal bir katılım formu oluşturduğu gerçeğini değiştirmeyecektir. Sosyal ağlar, kullanıcılarının birbirleriyle iletişim ve etkileşim kurmasını sağlaması açısından katılımcılık rolünün en canlı gözüktüğü kanallardır. Bu bağlamda küresel çerçevede en yoğun kullanılan Facebook başlıca örnek olarak gösterilebilir. Yine Facebook ile bağlantısı olan ve günümüzde "influencerlar" vasıtasıyla kişilerin gündelik hayat pratiklerine doğrudan etkisinin gözlemlenebildiği Instagram, popüler sosyal ağlardan biridir.

Kişilerin kendilerine ait paylaşımların mesleki boyut kazandığı daha profesyonel sosyal ağlar da mevcuttur. Bu sitelerde iş birliği kurulması, ortak paydadaki insanların bir araya gelmesinin sağlanması bu ağlar aracılığıyla mesleki mahiyette bir katılımın da internet ortamına taşındığını göstermektedir. Linkedin bu sosyal ağlara iyi bir örnektir.

\section{Facebook}

Sosyal ağlar arasında en yaygın kullanılan Facebook, kullanıcıların kendilerine ait profillerinde paylaşım yaparak sosyal çevreleriyle etkileşime girdikleri bir platformdur. Facebook kullanıcıları “arkadaş çevrelerini” ve paylaşımlarını kimlerin görüp göremeyeceğini belirleme imkânına sahiptir. Karşlıklı iletişimin ve etkileşimin yoğun olduğu bu platformda kullanıcıların kendilerine sanal "küçük bir dünya" (Görgülü, 2018) kurdukları belirtilebilir. Yukarıda da altı çizilen bu durum gerçeklikten bağımsız bir süreç gibi gözükse de aslında kendisi gerçekliğin bir parçası hâline gelmeye başlamıştır.

Facebook'ta kullanıcılar kendi kişisel hayatlarını paylaşmakla sinırlı kalmıorlar. Facebook verilerine göre her ay 3.5 milyondan fazla etkinlik Facebook'ta paylaşılmaktadır. Facebook'un kendi ortamının oluşturduğu katılım formunun yanında bu tür etkinliklerin paylaşılması, haberdar etme ve daha geniş çevreye erişme bağlamında önemli bir role sahiptir. Yukarıda açıkladığımız Twitter'ın ve Facebook'un özelde gençlerin katılımına en büyük etkisi de bu etkinliklerin daha büyük kitlelere ulaşmasında oynadığı rolde yatmaktadır.

\section{Instagram}

Fotoğraf paylaşım platformu olarak ortaya çıkan fakat gösterdiği gelişim ile birçok farklı boyutta etkinliği artan Instagram, en yaygın kullanılan sosyal medya vasitalarından biridir. Instagram'daki fotoğraflara "beğeni” atılması veya yorum yapılabilmesi yine kısmi bir katılım formu olarak değerlendirilebilecek hususlardır.

Fakat bununla birlikte Instagram'ın son dönemlerde kullanımı özellikle de "influencerların" yoğun kullanımı ve yüksek sayıdak 
takipçileri ile farklı bir form kazanmıştır. Reklam, tanıtım veya kişisel öykülerin sunulması gibi içerikler kullanıcıların bu kişileri daha çok takip etmelerine sebep olmuştur. Bu durumun katılım açısından önemi ise şudur: Takipçiler “direct message (DM)" yoluyla paylaşımı yapan kişilerle doğrudan iletişim sağlayabilmektedir. Bu durum sosyalleşmenin bir boyutu olarak karşımıza çıktığı gibi aslında kendi özellikleri içinde yeni bir katılım formunun sosyal medya araçlarıyla ortaya çıktığının göstergesidir.

\section{İçerik Paylaşım Siteleri}

Başta YouTube'un örnek verilebileceği bu sitelerde kullanıcılar profesyonellik gerektirmeyen düzeyde ürettikleri medyaları paylaşıma sunmaktadır. Bu sitelerde bloglarda karşılaşılan sınırlı etkileşim durumu söz konusu olmasına rağmen herkese temel birtakım dijital bilgilerle paylaşımcı olma imkânı tanıması bakımından önemlidir. Özellikle fotoğraf makinesi, kamera gibi cihazlara ulaşımın kolaylaşmasıyla bu medya kanalları birçok kişi tarafından aktif kullanılmaya başlanmıştır. Influencer gibi çok takipçisi olan ve kendi izleyicisi üzerinde etki bırakan kullanıcılara "YouTuber" denilmektedir. Yukarıda influencerlar ile bağlantılı olarak ortaya koyulan hususlar bu platformlar için de geçerlidir.

\section{Sosyal İmleme Siteleri}

Sosyal imleme siteleri, kullanıcıların beğendikleri web siteleri, internet sayfaları vb. hususları etiketleyerek takip etmelerini sağlayan sitelerdir. $\mathrm{Bu}$ siteler temelde sadece kullanıcının tecrübesine hitap etmektedir. Yine birtakım uygulamalar içerisinde etiketleme, dosyalama vb. hususların işlendiği görülmektedir. Örnek olarak yaygın müzik dinleme uygulaması olan Spotify'ın bu imleme yöntemiyle kullanıcılarına daha iyi bir müzik tecrübesi kurmaya çalıştığı gösterilebilir. Bu hususların katılım açısından önemini katılımcıların kendi listelerini, beğendiklerini diğer kullanıcılar için paylaşıma açabilmelerinde ve yine benzer şekilde paylaşıma açılan listeleri takip etme imkânlarında görülebilir. Yine “Goodreads, 1000kitap” gibi uygulamalar okunan veya okunması düşünülen kitapların paylaşılması, kullanıcılar arasında puanlamaların oluşturulması, kitaplara dair yorumların yapılması bakımından örnek olarak gösterilebilir. Sosyal imleme sitelerinde katılım bakımından dikkat çeken husus, kişilerin kendi tecrübelerini sosyal platforma aktarması ve bu aktarım vasıtasıyla sosyal çevreleri ile etkileşim kurmalarıdır.

Buaçıklamalardan hareketlesosyal medya kullanıcılığının beraberinde doğrudan içerik üreticisi olunmasa bile kendine münhasır bir katılım formu oluşturduğu söylenebilir. Doğrudan katılımın görece kısıtlı olduğu blog vb. platformların ise enformasyon ağını zenginleştirerek kişilerin ilgi alanlarında derinleşmelerine, etkinlikleri takip etmelerine, yaptıkları etkinlikleri duyurmalarına sağladıkları katkı çerçevesinde işlevsel olduğu belirtilebilir. Katılımın yoğunlaşması amaçlandığında katılımcıların bulunabileceği platformlar bunlardır. Nitekim bir katılımcı duyuru, afiş gibi yayılma yöntemlerinin artık gençler için niteliksiz olduğunu belirtmiştir. Yine aynı katılımcı gençlerin katılımını sağlamak için gençlerin bulunduğu ortamlara yönelinmesi gerektiğini vurgulamış bu alanların da Twitter, YouTube gibi araçlar olduğunu söylemiştir (Öğrenci, Erkek, 22).

\subsection{Sosyal Medya Etkileyicileri (Influencer)}

Bir sosyal katılım biçimi olan sosyal medya katılımında kullanıcılar bilgi, fikir ve deneyim paylaşımı yapmak için kullanılan sosyal ağ sitelerinde kendi arkadaşlık ağlarını da oluşturmaktadırlar. Bunun yanı sıra kimsenin iznini almadan bir hesabı takip edebilme özgürlüğünün ve karş1lıklı takipleşme (arkadaş olma) zorunluluğunun olmadığı platformlarda (Youtube, Twitter, Instagram) farklı bir katılım formunun geliștiği söylenebilir. 
Orijinalinde "Influencer" olarak isimlendirilen sosyal medya etkileyicileri "spesifik konular hakkında kişisel deneyimlerine dayalı içerik paylaşan ve bu paylaşımlar üzerinden geniş sayıda takipçi sayısına ulaşan bireyler” olarak tanımlanmıştır (Ünlü ve Zeybek, 2020). Profesyonel olmayan ve bireysel çabalarıyla sosyal medyada yaptığ paylaşımlarla, beğeni ve takipçi sayısını artıran kullanıcılara, mikro ünlü ya da fenomen de denmektedir (Sarıtaş, 2018). Yine aynı kişileri nitelemek için kullanılabilen fikir lideri (opinion leader) kavramı ise, belirli bir konu hakkında bilgisi ve uzmanlığı olduğu düşünülen ve fikirleri, tutumları, tercihleri ve eylemleri başkalarını etkileyen kişileri ifade etmektedir. Theresa M. Senft (2013), bu kişileri mikro ünlüler olarak isimlendirmiştir ve tanıma göre mikro ünlüler, video ve blog gibi sosyal medya mecralarını kullanarak internet aracılığıyla popülaritesini arttırmaya yönelik içerikler paylaşan, çevrim içi performans sergileyen kişilerdir. Bu genel kavramların yanı sıra Youtuber, Instagramer gibi ağa dair spesifik isimlendirmeler de yapılmaktadır.

Etkileyici (influencer), sosyal medya fenomeni ve fikir lideri kavramları literatürde birbiri yerine kullanılabilirken aslında etkileyiciler olarak ifade edilen influencerlar ile sosyal medya fenomenleri arasında ince bir farklılı̆̆ın bulunduğu da söylenmiştir (Tam, 2020). Bu iddiaya göre etkileyiciler daha çok pazarlama ve reklam alanlarıyla ilişkilendirilirken sosyal medya fenomenliği online platformlardaki ilk basamak olarak görülmüştür. Yani etkileyiciler, sosyal medya fenomenliğinin bir üst aşaması olarak nitelendirilmiştir. Aynı makalede fikir liderliği ise hem fenomen hem de etkileyicilerin ulaşılabilecekleri en üst aşamayı ifadede kullanılmıştır (Tam, 2020).

İnsanların günlük hayatlarını, giydikleri ürünleri, yedikleri yiyecekleri ve yaşam tarzlarını yansıttıkları ve bu şekilde tanınıp geniş bir kitleye ulaştıkları etkileşim aracı olan sosyal medya, kullanım oranlarındaki artışla en önemli reklam mecralarından biri hâline gelmiştir. Sosyal medya etkileyicileri aynı zamanda anlaştıkları markaların reklam yüzü olmaya başlamıştır. Her ne kadar ekonomik yönüyle dikkat çeken bir husus olsa da bu meseleye ayrıca kullanıcıların katılımları noktasından da bakmak önem arz etmektedir. Örneğin Instagram, moda sektöründe en çok kullanılan platformlardan biri olmuştur. Fikir liderleri/ etkileyiciler (influencer), topluluklar inşa etmeye ve anlık iletişim kurmaya imkân tanıdığı için yaygın olarak bu platformu kullanmayı tercih etmektedirler. Her ne kadar etkileyiciler moda üzerine takip ediliyor gibi görülse de bu kişileri takip etme ve etkileşime girme motivasyonları farklılaşmaktadır. Bir Instagram influencerı (Kadın, 25) ile yapılan mülakatta bu motivasyonların sadece moda takibi olmadığı, insanların sayfa sahibinin hayatını merak ettikleri hatta takip ettikleri kişilerle aynı çizgide yürümek istedikleri belirtilmiştir. Katılımcının "Beni takip eden bu yüzden takip ediyor, nereye gitmiş diye bakıyorlar; ne yemiş, ne dinlemiş, ne yemek yapmış? Ben bununla var oluyorum.” cümlelerinden tek motivasyonun tüketim ve moda olmadığı anlaşılabilir. Metnin devamında etkileyicilerin özelliklerine, etkileyicilerin ve takipçilerin bu sosyal ağa katılım motivasyonlarına değinilecektir.

Etkileyici ve etkileyen ağına katılmada kendini ifade etme, kimlik paylaşımı ve topluluk aidiyeti kişisel motivasyonu sağlayan faktörlerdendir (Matikainen, 2015). Kendini ifade etme ve kimlik paylaşımı, kendi yaşamlarını başkalarına aktarma isteğiyken çevrim içi topluluklara ait olma ve etkileşimi sağlama da katılımı artıran bir motivasyondur. Influencerların kendi hayatlarını büyük oranda sosyal medyada ortaya koyuyor olmaları takipçileri ile aralarında bir iletişim dilinin oluşmasına sebep olmaktadır. Bununla beraber kullanıcıların bu kimselere doğrudan ulaşmak için sahip oldukları vasıtalar (örneğin DM), kullanıcı ile influencer arasındaki etkileşimi güçlendirmek bakımından önemlidir. Kullanıcılar bu araçlar yoluyla yeni bir sosyal çevreye 
ulaşmaktadırlar. Örneğin kendisini influencer olarak niteleyen bir katılımcı "Hayatımı ne kadar doğal yansıtırsam takipçilerim beni o kadar arkadaşı olarak görüyorlar.” cümlesiyle kurulan ilişkilerin arkadaşlık ilişkisine benzetilebildiğini ve gerçek bir ilişki olarak görüldüğünü göstermektedir. Aynı katılımcı gençlerin kendilerine ilgi gösterme sebeplerini "Gençler kendi ilgi alanlarını keşfetmek ile uğraşmak istemiyorlar. Bunun yerine birilerinin yaptıklarını taklit etmek ve bunları benimsemek onlara daha kolay geliyor. Bu sebeple de bizi takip ediyorlar.” şeklinde belirtmiştir. $\mathrm{Bu}$ ifadelerden gençlerin bir hayat tarzı kurmak ve kendilerini ilişkilendirmek için sosyal medya influencerlarını takip ettiğini çıkarabiliriz. Influencerlar ile iletişim kurmak ve kendilerini onlarla bağdaştırmak gençlerin kendilerine dair bir hayat yaklaşımını sosyal medyada bulduklarının işaretidir. Katılım perspektifinden bu duruma baktığımızda burada kendine has bir katılım biçimi ile karşı karşıya olduğumuzu söyleyebiliriz. Bu katılım biçimi her kullanıcı için aktif bir şekilde seyretmese de büyük bir kesimin hayat tarzı, ilgi alanları, moda, eğitim, hobi vb. hususlarda kendilerini bağdaştırdıkları içeriğe doğru eğilimin olduğunu bir şekilde göstermektedir. Bu içeriğe ulaşma ve bir anlamda "opinion leader” arayışı sürecinde influencerlar aktif rol oynamaktadırlar. Mülakat esnasında katılımcı, tesettüre girmeye ilişkin sorular ile muhatap olduğunu ve tavsiye istendiğini söylemiştir. Bu konunun tesettürlü bir influencera danışılması, kişinin kendi tecrübesine ilişkin önemli kararları alırken internet ortamındaki kişilerle kurduğu güvenin ve bağın göstergeleridir. Öyleyse influencerın düşünce ve davranışlarının diğer kişilerde doğrudan veya dolaylı yoldan yankı bulduğu göz önüne alındığında kendilerinin katılım sürecinin başlıca aktörleri olduğunu söyleyebiliriz. Yine katılımcı kendisine yurt dışına çıktığında "Neden gittin? Dil biliyor musun? Nereleri gezdin?” gibi soruların sorulduğunu söylemiştir.
$\mathrm{Bu}$ durum, sosyal medya kullanıcılarının yaşayan tecrübeyle doğrudan iletişimini sağlamaktadır. Dolayısıyla etkileyicilerin görüşüne, tecrübelerden istifade imkanı için başvurulduğu görülmektedir. Yaşayan bir tecrübe olarak etkileyicinin kendi hayat hikâyesini sunması kullanıcıları bir anlamda o tecrübenin bir ortağ1 yapmaktadır. İleride bunu amaçlayan veya hayal eden kullanıcılar için ulaşılabilirliği göstermesi bakımından önemlidir. $\mathrm{Bu}$ nedenle kullanıcılar tecrübenin detaylarına vakıf olarak bir anlamda "influencerın tecrübesine katılmak" istemektedirler. Özellikle gençlerin dikkatlerini çekmek ve onların hayatlarında yansımasını daha çabuk ve etkili bir şekilde görmek için influencerların oynadığı rol açıktır.

Fikir liderleri kişisel, sosyal ve sosyodemografik özellikler açısından incelendiğinde kişisel özellik olarak yenilikçilik, katılımcılık, sosyal ortamlara uygunluk, toplumsal ve alanıla ilgili konularda bilgili ve anlayışlı bir mizaca sahip olmasından bahsedilmiştir (Weimann, 1994). Fikir liderlerinin, yaratıcılıklarının ve toplumdan farklılaşmaya istekli oluşlarının yaptıkları aktarımda etkili olduğu görülmüştür (Chan ve Misra, 1990). Toplumun geri kalanından farklı olma isteği, bu sayede topluma yön verme isteğiyle paraleldir. Bunu destekler biçimde, Instagram etkileyicisi olan bir katılımcı da (Kadın, 25) paylaşımları aynılaştığı zaman, benzer şeyleri paylaştıklarında insanların onlara bir şey katmayacağını düşündüklerinde takip etmeyi bıraktıklarını söylemiştir. Paylaşımları farklılaştığında, içerik değiştiğinde, bilmedikleri konularda da bir şeyler göstermeye başladığında ise etkileşimin daha çok arttığını gözlemlemiştir. Takipçilerin yaşayamadıkları hayatı görmeyi talep ettiklerini söyleyen katılımcı, takipçilerin bu isteğini "Biz sosyal medya ile insanların evinin penceresinden içeri bakıyoruz, konuşmalarını duyabiliyoruz, herkesin evine girebiliyoruz. İnsanlar da merak ettikleri eve bakmak istiyorlar, kendinde olmayanları merak ediyorlar.” cümleleriyle açılklamış ve takipçilerin farklılık arayışını dile getirmiştir. 
Sosyal özellik olarak sosyal aktiviteleri başlatma ve yönetebilme kabiliyeti, herkes tarafından ulaşılabilirlik, bilinirlik ve toplumun güvenini kazanma gibi özellikler öne çıkmaktadır (Weimann, 1994). Ulaşılabilirlik özelliğine değinen bir katılımcı "Bana DM yoluyla tesettür hakkında soru sorup kapanmak istediklerini anlatan takipçilerim var.” (Influencer, kadın, 25) diyerek aslında takipçi ile içerik üreticisi arasında özel ve samimi bir iletişim kurulabildiğini göstermiştir. Aynı diyalog içerisinde özelini yansıtmayan, sınırlarını daha keskin çizen hesapların ütopik kaldığını ve daha ulaşılır hesaplara göre daha az tercih edildiğini belirtmiştir. Konuştuğumuz sosyal medya etkileyicisi, gündemle ilgili fikirlerden özel günde giyecekleri kıyafet tavsiyelerine kadar birçok mesaj aldıklarını ve cevapladıklarını söylemiştir. Bu da kendilerinin herkes tarafından ulaşılabilir olduklarını gösteren bir davranış olarak görülebilir.

Sosyodemografik özelliklere ise etki alanlarına göre profil değişikliğine gitme, hitap ettiği kitlenin toplumsal ve kültürel özelliklerine bürünme ve etkili olduğu alandaki kitlelerin profillerine benzeme eğilimi gösterme gibi özellikler örnek verilebilir (Weimann, 1994). Fikir liderlerinde bulunan farklılıkla kişisel özelliği ile çelişebilir gibi görünen bu özellik arasında bir denge kurulması gerekmektedir. Yapılan mülakatta görüldüğü üzere insanlar kendilerinde olmayana ve değişikliğe talip olurken aynı zamanda sosyal medya etkileyicisi olan katılımcı deyimiyle "takip ettikleri etkileyiciler ile aynı çizgide yürümeyi” istemektedirler. Aynı çizgide yürümek ve ilerlediği yolu, giydiği kıyafeti, fikirlerini takip etmek istedikleri kişinin kendilerinden çok uzak bir profilde olması da mümkün değildir. Bu yüzden sosyal medya etkileyicileri, fikir liderleri kitleleri ile benzer profile sahip olurken aynı zamanda tercihleriyle bir farklılık sunmaktadırlar. Birçok kategoride fikir lideri ve özelliği arasında farklı ilişkiler bulunmuştur. Örneğin, bir çalışmaya göre yiyecek konusundaki fikir liderleri genellikle evli ve geniş ailelere sahipken; sinema konusundaki fikir liderleri genç ve bekâr olmaya yatkındır (Chan ve Misra, 1990). Benzer bir kategorilemeyi Instagram fenomenlerine yaptığımızda genellikle yakın yaşlarda ve yakın çevrelerde bulunduklarını görebiliriz.

$\mathrm{Bu}$ platformun ve etkileyiciliğin iş boyutuna gelirsek Influencer marketingin amacı, etki gücüne sahip olan kişiler sayesinde hedef kitleyi markaya yönelten mesajlar iletmektir. Influncerların karar verme ve satın alma süreçlerindeki etkisinin nedeni üzerine odaklanan çalışmalar, tüketicilerin izlediği kişi gibi veya izlediği kişiyle olmayı istediği sonucuna ulaşmıştır. Bu yüzden de influencerlar, takipçilerine kendileri gibi olmanın yolunu sunmaktadırlar (Oyman ve Akınc1, 2019).

Yapılan araştırmalar kişiler arası kaynakların tüketici kararlarına geleneksel reklam tekniklerinden daha güçlü etki ettiğini göstermiştir(Goldsmith and Clark 2008). Sosyal medya etkileyicileri, sosyal medyanın kullanımıyla takipçi tutumlarını şekillendiren bağımsız üçüncü tarafonaylayıcı tipini temsil etmektedir(Veirman, Caugberghe ve Hudders 2017). Günlük hayatta başkalarının fikirlerini değerlendirme davranışımız sosyal medyanın gelişmesiyle birlikte bire bir paylaşımlar için yetki sağlamıştır. Kararlarını oluşturacak fikirleri edinmek için tüketiciler sık sık sosyal medyaya başvurmaktadırlar. Chan ve Misra (1990)'ya göre tüketiciler karar verme süreçlerinde firma reklamlarından çok fikirlerine önem verdikleri etkileyicilerin tavsiyelerini dikkate almaktadırlar. Çünkü bu mesaj çok daha gerçek ve güvenilir görülmektedir. Tüketicilerin ürün seçimi ve partilere oy verme davranışlarını inceleyen iki aşamalı akış teorisine göre kişiler doğrudan siyasi partilerin mesajlarını dikkate almaktan çok, aile ve arkadaş ağlarındaki önemli kişilerle ilişkilerindeki mesajları önemsemektedir. Mesajların iletim biçimi olarak iki aşamadan 
geçtiğini ifade eden bu modelde ilk aşama mesajların fikir lideri olarak ifade edilen kişiye ulaşması ve ikinci aşama ise bu liderlerin bilgiyi çevrelerine aktarmasıdır (Tam, 2020).

Özetle sosyal medya etkileyiciliği hem üretim hem tüketimle sosyal katılımın sağlandığı bir mecradır. Bu katılım formunun motivasyonları, hedefleri ve sonuçları farklılık göstermektedir. Kullanılan sosyal ağ platformuna göre formu değişen etkileyicilik için birçok farklı platform seçeneği ve kendilerine has kriterleri mevcuttur. Sanal katılımın artmasıly birlikte bu mecralarla birlikte etkileyicilerin de çeşitlenip çoğalması, yeni formlar oluşması beklenmektedir. Bu katılım türüne olan rağbetten çıkarılan motivasyonlar değerlendirilmeli ve gençliğin dönüşen katılım formları ve ilgileri göz önünde bulundurularak sosyal katılım faaliyetleri dönüştürülmelidir. İnsanların etkilemek veya etkilenmek istedikleri noktaların dikkate alınıp sivil toplum kuruluşları, vakıf ve dernekler tarafindan yapılan projelerde bu ihtiyaçların göz ardı edilmemesi gerekmektedir.

\subsection{Anonim Katılım}

Mülakata katılan öğrenciler tarafindan gönüllülükte tercih edildiği belirtilen aktif katılımın aksine, sosyal medyada anonim katılım da çok tercih edilen katılım türlerindendir. Aktif katılımda kişiler ön planda olmak isterken ve görünür olmayı katılım motivasyonu olarakgörürken diğer tarafta görünür olmak istemeyen katılımcılar yer almaktadır.

Dijitalleşmeyle birlikte insanların sosyalleşebildikleri kanallar da çoğalmıştır. Alternatif kanalların oluşmasıyla farklı sosyalleşme formları da ortaya çıkmıştır. Sosyalleşme formlarından biri olan anonim katılım, yeni medya düzeniyle yaygın kullanıma ulaşan sosyal medya platformları üzerinde bireyin tercih ettiği sosyalleşme türüdür.
Helen Nissenbaum (1999) anonimlik durumunu "erişilemezlik ulaşılamazlık” olarak tanımlanmıştır. Başkaları tarafından tanınmama durumu, anonim katılımcıyı erişimden münezzeh kılmaktadır. En az bir farklı kişiden oluşan bir kitle gerektiren anonimlik, ironik biçimde sosyal olarak tanımlanmaktadır. Çünkü kimseyle etkileşim içinde olmadan ve fark edilmeden yaşayan birine anonim demek mümkün değildir (Marx, 1999). Bu yüzden anonimlik sosyal katılımın temel alt başlıklarından biri olarak görülebilir.

Anonim katılım, bireyin kendini güvende hissetmesine ve hayalini kurduğu kimliği inşa etmesine olanak sağlamaktadır. Sosyal medya vasıtasıyla kullanıcılar, gerçek kimliklerini gizleyebilir ve yeni bir tane oluşturabilirler. Güvenlik endişesi, mahremiyet, sahip olunan kimliği beğenmeme, hayal edilen kişiyi oluşturma gibi nedenlere bağlı olarak doğan ihtiyaç, anonim katılımın tercih edilmesini sağlayacaktır. Aynı zamanda bireyler katılım sağladığı sosyal alanlarda kimliklerini gizlemeyi tercih etmektedirler. Bu tercihin en önemli sebepleri kuruma olan güvensizlik, zarar görme endişesi, sorumluluktan kaçınma, kişisel bilgi mahremiyetini koruma ihtiyacıdır.

\begin{abstract}
"Anonim olmak, sosyal medya ortaminda daha rahat ve özgür hareket etme yönündeki motivasyonları da güclendirmektedir. Kimse gerçek kimliği veya kişinin özelliklerini bilmek zorunda değildir. Bu sayede sosyal medya kullancclan istenmeyen, stresli özelliklerini gizleyebilir ve başkalarmmn benimsediği bir kiși olabilir. Fiziksel görünüm, utangaçlk, düșük benlik saygısı vb. gibi istenmeyen özellikler bu sayede gizlenmiş olmaktadır. Aynı zamanda sosyal medya aracığyla gerçekleştirilen iletişim, anonimlik duygusunun gelişimini sağlar ve bu durum yüz yüze iletişimden daha az kayglya neden olur." (Gölcü, Balcı, Arsal, 2019)
\end{abstract}

Anonim katılımı, öz kimliği beğenmeme ve arzu edilen kimliğe sahip olmak için tercih eden bireylerin mevcut özelliklerini kabul etmeme, beğenmeme durumlarına bağlı olarak toplum içinde öz 
güven kaybı, utangaçlık, kendini ifade edememe gibi durumlarla karşılaşması olasıdır. Dijital dünyanın sağladığı imkânlar ile sosyalleşme tatminini sağlayan bireyin toplum içinde tutunamaması ve sorunlar karşısında mücadele yetisini kaybetmesi de kaçınılmaz olacaktır. Mahremiyeti koruma ve kendini güvende hissetmek için tercih edilen anonim katılım, bireyin kendisini koruması kadar başkalarının özel alanına saygı duymasını da sağlayabilir.

Anonim katılımın tercih edilme sebepleri fikir beyanının sonrasındaki güvensizlik, grup tarafindan dışlanma veya kabul edilmeme gibi sebepler olabilir. Özellikle Twitter fikir beyan etmede, gündem oluşturmada ve grupları etkilemede sahte kimliklerin çokça kullanıldığı bir platformdur. Linç kültürünün de oldukça yaygın olduğu bu platformda isimler bir ana hedef hâline gelebilmektedir. Aynı zamanda anonim olmayan katılımcılar beyan ettikleri fikirlerinin kariyerlerine de etki etmesinden çekinmektedirler. Raporun güven başlığı altında bu düşünceye sebep olan etkenlerden detaylıca bahsedilmiştir. Anonimlik, katılımcılara güvenli bir fikir beyan etme alanı tanımaktadır.

İnsanları anonimliğe iten sebepler gerçek hayattaki sosyal katılımın düşmesinin sebepleriyle paralel olarak okunabilir. Sosyal katılımı zorlaştıran faktörlerden olan güven maddesi bu durumda etkisiz hâle gelmektedir. Anonimlik, yalnızca çevrim içi platformlarda kullanılan bir sosyal katılım biçimi değildir. Günlük hayatta sivil toplum kuruluşları, vakıf ve dernek katılımları ve gönüllülük faaliyetlerinde de fotoğraflarda görülmeme ve üyelik vasıtasıyla kişisel bilgi paylaşmama söz konusudur. Bu katılım şeklinde katılımcılar, faaliyetlerde yer almayı, dinlemeyi, konferans ve eğitimlerden yararlanmayı tercih edip kurumla bir bağlılık oluşturmamaktadırlar. Bu sayede sosyal katılım motivasyonlarından bazıları yerine getirilirken katılımı zorlaştıran faktörler de elimine edilmiş olmaktadır.
Sivil toplum kuruluşları, farklı kaygılardan dolayı artan bu katılımın kaygılardan kurtulması için çaba sarf edebilir. Örneğin, kuruma güvensizlik ve bilgilerin paylaşımı veya kullanımına dair endişelerden kaynaklanan anonimlik bu konuda güven verildiği takdirde yerini aktif ve kişisel katılıma bırakabilir. Raporun farklı kısımlarında detaylandırılan gelecek kaygısı veya güvensizlik duyulmasina sebep olan hususlar tespit edilip bu konudaki endişeler azaltılmaya çalışılabilir. Programlarda istenen kişisel bilgiler azaltılarak aslında ihtiyaç duyulmayan detay bilgilerin toplanması sınırlandırılabilir. Vakıfların yalnızca kendi içlerinde yaptıkları programlardan ziyade daha farklı kurumlarla iş birliğiyle hazırlanan programlar katılımları artırabilir.

Anonimliği sağlayan fakat aynı zamanda veriyi denetleyen bir kontrol mekanizması kurulmalıdır. Kurumların veriye erişimi kısıtlanmalı, devletin bu bilgiye ulaşımı artırılmalı, siyasi görüşleri kriminalize etmeden hakaret gibi gerçek suçlar takip edilmeli ve bu mekanizma ile bir yandan kişilerin anonim kalma, gizlilik gibi hakları korunurken diğer yandan kişilere vereceği zarar da engellenmelidir. Sosyal medyada kullanıcılarının devlet tarafından korunması da fikir beyanında linç korkusu veya farklı endişelerle kimlik gizlemeyi azaltacak bir mekanizma olabilir. Son olarak anonim katılımın bir ihtiyaç olduğu kabul edilmeli fakat normalleşip kimlik kaybına, farklı kişilere zarar vermeye yol açmaması için de çaba sarf edilmelidir.

\subsection{Dijital Katılım}

\subsubsection{Sosyal Medya Savunuculuğu}

Twitter adaleti veya sosyal medya mahkemesi gibi kullanımlar ülkemizde hepimizin aşina olduğu ve hatta bir şekilde parçası hâline geldiği bir süreci nitelendirmektedir. Toplumun 
vicdanında yer eden fakat devlet eliyle aksiyonun alınmadığı veya alınan tedbirlerin eksik kaldığı hususlarda toplumun sosyal medya üzerinden "örgütlenerek" sesini duyurmaya çalıştığ1 durumları ifade eden bu kelimeler özellikle de bu platformların yaygınlaşmasıyla gittikçe önemini artırmaktadır. Sosyal medya ile bu savunuculuk hareketlerinin kesişmesi de artık literatürde önem arz etmeye başlayan ve üzerinde çalışmaların yapıldığ alanlardan biri hâline gelmeye başlamıştır (Saxton, Niyirora ve Waters, 2018). Bu savunuculuk hareketleri sosyal medyanın kendi sanal gerçekliğini kurduğunu ve kullanıcılarına bu gerçekliğin bir parçası olması bakımından kapı araladığını göstermektedir. Keza sosyal medya ile bireyler arası iletişimin şekli değişmiş, eylemler farklı bir form kazanmış ve bu da toplumsal hareketlerin kaderini de yakından etkilemiştir (Aksulu, 2013). Fakat burada sosyal medya vasıtasıyla gerçekleşen aktivizmler arasında bir ayrım yapmak önem taşımaktadır. Bu konuda karşımıza çıkan ikili tipolojiye dayanan ayrım, sosyal medyanın toplumsal aktivizm ve savunuculuk hareketlerindeki rolünü sunmak bakımından işlevseldir. Bu ayrım şu şekildedir: İnterneti toplumsal eylemi mobilize etmek için kullanan aktivizm ve internet tabanlı başlayıp sonuçları da yine çevrim içi platformlardan takip edilen eylemler (Van Laer ve Van Aelst, 2010). İlk tür eylemlere küresel çapta Wall Street ve Arap Baharı hareketleri, ülkesel bazda ise Gezi olayları örnek olarak gösterilebilir. İkinci türe ise kadın cinayetlerine karşı kamuoyu tepkisinin oluşturulması, çevrim içi platformlarda imza kampanyalarının yürütülmesi gösterilebilir.

Savunuculuk hareketlerinin bir alanı olarak sosyal medyanın kullanıcılarına nasıl bir imkân tanıdığı sorusu önemlidir. Kişilerin gündelik hayatın akışında reaksiyon oluşturdukları birçok meselede kendilerini ifade etmeleri için ulaşılabilir ve pratik bir araç olma imkânı bu soruya verilebilecek bireysel bazlı bir cevaptır. Bu noktadan devam edecek olursak kişilerin kendilerini toplumsal olaylardan etkilenen bir bütünün parçası olarak görmesi ve kolektif tepkiye kendilerinin de katkı sağlamaya yönelik motivasyonları önemlidir. Örneğin bir olaya ilişkin tepkisini o mesele için kullanılan hashtag ile paylaşan kullanıcı bu hashtag ile ilgilenen kişilerin kendi paylaşımına ulaşacağını ve tepkisinin bu kollektivite içerisinde anlamlı olduğunu düşünecektir. $\mathrm{Bu}$ bağlamda hashtagler kullanıcilara bir toplumsal hareketin, aktivizmin veya savunuculuğun katılımcısı olma imkânı sunmaktadır (Saxton ve ark., 2018). Bu davranışların bir nevi "kolay aktivizm" olduğunu ve gerçek toplumsal sorunlara çözüm bulma sürecini baltaladığını iddia eden görüşler de vardır. Ancak sosyal medyanın sağlamış olduğu çeşitli pratiklerin katılımın kuvvetini artırdığı dikkate alındığında özellikle bireysel boyutu ile önemli bir katılım formu olduğunu belirtmemiz gerekir (Aktaş ve Akçay, 2019).

Sosyal medyada bu tür aktivist eylemlerin içinde yer almanın bireylerin öznel katılımının yanında toplumsal bir güç oluşturularak örgütsel mahiyette bir katılım formu oluşturduğuna dikkat çekmekgerekmektedir. Gönüllü kurumların sosyal medyada kamuoyu oluşturarak toplumun diğer kesimlerine ulaşmaları ve kendi hareketlerine destek oluşturmaları bu durumun bir veçhesidir (Guo ve Saxton, 2014). Bu şekilde gelişen katılım formunda kurumların kendi organizasyon çatıları altında gerçekleşen aktivizm ve savunuculuk faaliyetleri, gerçek hayatta bu kurumlarla organik bağı olmayan ama söz konusu meselede oluşan örgütselliğe dâhil olmak isteyen kişilere imkân sunar. Kurumlar kendi faaliyetlerini gerçek hayatta devam ettirirken hem faaliyetlerin dinleyici kitlesini artırmakta hem de sosyal medya ortamından ulaştıkları bir gücü arkalarına almış olmaktadırlar. Bunun yanında herhangi bir organizasyonel altyapiya dayanmayan birtakım hareketler de yukarıda altını çizdiğimiz bireysel katılım formunun bir araya gelmesiyle sesini duyurabilecek bir toplumsal boyut kazanmaktadır. Bu duruma ülkemizde kadın cinayetleri ile bağlantılı oluşturulan kamuoyunun soruşturma süreçlerinde alınan tedbirlerde etkili olduğu bazı davaları örnek gösterebiliriz. 
Bu açılklamalardan yola çıkarak sosyal medya üzerinden gelişen farkındalığın kullanıcılarına sunduğu imkânların bireysel ve toplumsal katılım formlarını yeniden dönüştürdüğünü ve yeni şekiller içerisine soktuğunu söyleyebiliriz. Bireysel boyutta kişilerin belirli aktivizmlerle ilgili ifadelerini açıklamak için imkân bulmaları, kendileri gibi düşünenlerle bir ağ oluşturmaları, karşıt görüştekilerle istişare ederek meselenin farklı yönleriyle tanışma olanağı bulmaları önemlidir. Bu durum kişilerin yaşadıkları toplumla oluşan duyarlılık seviyelerini etkilemekte aslında "sanal bir mecra vasıtası ile bireyleri gerçek toplumun bir katılımcısı” hâline getirmektedir. Bununla beraber bu katılım formları birleşerek kolektif hareketlerin doğmasına veya hâlihazırda devam eden aktivizmlerin daha büyük güç bulmasına da imkân sağlamaktadır.

Özellikle genç nüfusun toplumsal olaylara karşı hassasiyetleri ve bu olayları takip etmek için de yoğun bir şekilde sosyal medya mecralarında takip ettiği hususlar dikkate alındığında genç nüfusun mobilize olduğu bir katılım formu olarak sosyal medya savunuculuğu ayrıca dikkat çekicidir. Gençlerin nabızlarının ölçülmesi, onları toplumsal hareketlerin parçası hâline getirmeyi sağlaması, örgütlenme ve karşılaştıkları sosyal problemlere karşı ses çıkarma tecrübesini sunması bakımından sosyal medya ve bu mecrada gerçekleşen savunuculuk faaliyetleri ciddi bir önem taşımaktadır. Gençleri motive ederek bir hareketlendirmenin oluşturulması açısından bu mecraların sağladığı imkânlar çok geniştir ve biraz da olumlu anlamıyla manipülasyona açıktır. Bu mecralarda oluşan hareketlerin seyri iyi tahlil edilerek gençlerle bir iletişim ve etkileşim vasıtası olarak verimli kullanımı mümkündür.

\subsubsection{Fotojenik Katılım}

Sosyal medyadaki bazı platformlar, görsel materyallerin paylaşımının yapılmasına dayanmaktadır. Bu platformların başında Instagram gelmektedir. Fakat görsel paylaşım, özellikle de bireylerin kendi görüntülerinipaylaşmalarıyalnızca Instagramözelineindirgenebilecek bir durum değildir. Birçok platformun profil oluştururken fotoğraf talep etmesi başta olmak üzere kişilerin kendi görüntüleriyle sosyal medyada var olmaları artık kaçınılmaz bir olgudur. Bireyi bu paylaşımları yapmaya iten sebep ise sosyal medya mecrasında kendisini sunabileceği bir profil kurgulama güdüsüdür. Her ne kadar bazı yazarlar bu durumu otantik gerçeklikten bir kopuş olarak değerlendirseler de (Bostancı Ege, 2017) aslında farklı bir gerçekliğin oluşturulduğu dünyaya ayak uydurma olarak değerlendirilmesi de mümkündür. Bu durum, aslında sosyal medyanın bir parçası olmanın gerekliliklerini yerine getirmek anlamına gelmektedir.

Fotojenik katılım başlığı altında karşımıza çıkabilecek en önemli paylaşımların genelde özçekimler (selfie) olduğunu söyleyebiliriz. Yapılan bir çalışmada ergenlerin özçekim paylaşımlarının altında yatan sebepler araştırılmıştır. Bu çalışmanın sonuçlarına göre gençlerin yarısından çoğu özçekimi yalnızlıkla mücadele yöntemi olarak kullanmaktadır (Aktu ve Bedrettin, 2019). Yaptıkları paylaşımların alacağı etkileşimle hissettikleri yalnızlıktan kurtulacağını düşünen gençlerin kendi fotoğraflarını paylaşarak sosyal medyanın bir katılımcısı rolüne büründüklerini söyleyebiliriz. Burada klasik anlamda bir yalnızlıktan kurtulmaktan bahsedemeyiz ancak paralel bir katılım formu olarak bu paylaşımlarım katılımı yükselttiğini belirtebiliriz. Yine bu araştırmanın sonuçlarına göre gençlerin dörtte birinden fazlası özçekim paylaşımlarını arkadaşlarına özendikleri için yaptıklarını belirtmiştir. Özenti durumu da kullanıcının kendini sosyal mecrada geri kalmayan bir katılımcı olarak göstermesinin bir yolu olarak değerlendirilebilir.
Gençlik ve Sosyal Bir Literatür

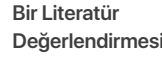


Sosyal medyanın özellikle görsel ağırlıklı platformlarında kullanıcıların kendi görselleriyle rol aldıkları açıktır. Bu paylaşımlarda amacın sosyal medyanın "kurguladığı” dünyanın bir parçası olduğunu göstermek olduğunu belirtebiliriz.

\subsubsection{Dijital Oyun Katılımı}

Dijital oyunlar, bireyin elektronik bir sistem üzerinden etkileşimli bir şekilde oyun oynamasını ifade etmektedir. Tarihte ilk dijital oyununu 1962 yılında Steve Russell ve arkadaşları yapmıştır. Russell ve arkadaşları ilk etkileşimli dijital oyununu MIT'de (Massachussets Teknoloji Enstitüsü) Spacewar (Uzay Savaşı) adı ile çıkartmışlardır. İlk dijital oyun olan Spacewar, iki kişinin kontrol ettiği iki farklı uzay gemisinin düşman uzay gemileriyle savaştığı bir oyundur (Yılmaz \& Çağıltay, 2004).

Dijital oyun dünyasının başlamasıyla, salon oyun konsolları üreticisi olarak bilinen aynı zamanda ABD'deki ilk oyun şirketi olan Atari firması, 1972 yılında çıkarttığı Pong adlı salon tipi oyun konsoluyla pazarın \%80'ine egemen olmuştur. Dijital oyun sektörüne olan ilginin artmasıyla oyuncuların dijital oyunlara ulaşımı zorlaşmış ve bu sebeple Atari firması 1980 yılında ilk taşınabilir oyun konsolu olan Atari VCS'yi (video bilgisayar sistemi) çıkartmıştır. Televizyon ile entegreli bir şekilde çalışan bu konsollar ylllar sonra beraberinde CD-Rom teknolojisinin gelişmesine önayak olmuştur. CD-rom teknolojisi 1994 yılında Sony firması tarafında geliştirilip oyunların bir CD içerisinde depolanmasını, görsel ve ses efektlerin oyunlara entegre edilmesini sağlamaktadır. Teknolojiyle birlikte gelişen oyun sektörü, 2006 yılında altıncı nesil olarak bilinen Playstation ve Xbox oyun konsollarının çıkması ve son olarak 2016 yılında sanal gerçeklik olarak bilinen VR oyunların çıkmasıyla gelişimini sürdürmektedir (Dijital Oyun Tarihi).
Gaming in Turkey Oyun ve Espor Ajansı, Türkiye'nin 2019 yılında oyun sektörünü araştırmıştır. Araştırmaya göre 2019 yılında Türkiye'de \%57,2'si erkek, \%42,8'i ise kadın oyuncu olan toplam 32 milyon oyuncu bulunmaktadır. Yaş aralıklarına göre çoğunluğu \%34,95 oran ile 25-34 yaş arasındaki oyunculardan oluşurken $\% 28,60$ ile 35 - 44 yaş arası oyuncular, \%21,87 ile 18-24 yaş aras oyuncular, \%11,21 ile 45-54 yaş arası oyuncular, \%3,36 ile 55-64 yaş arası oyunculardan oluşmaktadır. Türkiye'de en çok indirilen ücretsiz oyun 15,3 milyon ile Pubg Mobile - Tencent olurken; ücretli oyun olarak ise 69 bin indirilme ile Minecraft PocketEdition - Mojang olmuştur. Bu oyuncular arasından 2019 yılında 1515 kişi lisanslı Esporcu olurken oyuncuların yer aldığı lisanslı 85 tane Espor takımı vardır (Gamıng in Turkey, 2019).

Dijital oyunların gelişmesi ve kullanımının artmasıyla insanların sosyal kimliklerinin ne yönde şekillendiği merak konusu olmuştur. Bu konuda Jesper Juul, dijital oyunların kurgusal bir yapıdan öte olduğunu ve bu yapıyı birtakım kuralları ve sistemi olan ve insan ilişkilerini yapılandıran bir sanat biçimi olarak tanımlamaktadır (Juul, 2003). Bireyin sosyal statüsünü geliştirmesi için kullandığ bir araç olan dijital dünya, içinde bulundurduğu fonksiyonlarla bireyin sosyalleşmesine yol açmaktadır. Bu fonksiyonlardan biri olan dijital oyun katılımı, bireyin dijital oyunlarda farklı kültürlere sahip bireylerle etkileşim kurmasını ve uyum içinde ortak amac gerçekleştirmesini sağlamaktadır.

Bireyin sahip olunması zor olduğunu düşündüğü birtakım şeylere dijital dünyada kolay ve kendini güvende hissederek ulaşması durumu, onu oyun dünyasına itmektedir. Bu durumun oluşmasıyla bireyin gerçek dünya sorumluluklarından kaçması ve mücadele etme yetisine olumsuz etki etmesi olasıdır. Yapılan mülakatta katılımcı "Dijital oyun dünyasında iletişimin daha kolay olduğunu ve bireyin kendini daha rahat ifade etmesine 
olanak sağladığını aynı zamanda farklı kültürlerle bağ kurabilme ortamına sahip olduğunu" (Öğrenci, Erkek, 18) ifade etmiştir. Çevrim içi oyunlarda bireyler farklı kültürlere sahip kişilerle iletişim hâlinde oyun oynamaları durumunda sosyal becerilerinin gelişmesi, yardımlaşma davranışının gelişmesi, grupça hareket etme ve iş birliği yapma, strateji yapma, problem çözme, sorumluluk alma, öz güven kazanma ve kendini iyi ifade etme gibi olguları kazanmaktadır. Yapılan mülakat sonucunda bir katılımcı oyunlar hakkında şunları söylemiş̧ir:

"Çevrim içi oyunlarda bireyler, öz kimliklerinin yanında farklı bir kimlikle iletişim kurabilme eğilimi göstermektedir. Bu eğilimin oluşmasıyla gerçek dünya iletişiminde yer alan mekân, zaman, öz kişilik olgularını dijital dünyada gerçeklik derecesinin düsü̈k olmasından dolayı iletişimde kırılmaların yaşanması kaçınılmazdır." (Öğrenci, Erkek, 18)

Dijital oyunlar, bireyin gerçek yaşamda karşılaşabileceği olay ve durumlar karşısında çözümleme, adlandırabilme, edindiği deneyimleri uygulama açısından olanaklar sunmaktadır. Dogbeh ve N'Diaye, Bloom'un bu konu hakkında yaptıkları araştırma sonucunda oyunların birey üzerinde var olan bilişsel ve eğitsel amaçlarının olduğuna değinmişlerdir. Bunlar; doğrudan bilgilenme, anlama, uygulama, analiz, sentez, keşfetme, değerlendirme ve yaratmadır (İgit, 2020).

Dijital oyunlar, bireylerin bilişsel gelişimi ve öğrenme yetileri için çok önemli bir etkinliktir. Bireyler keşfetme, inceleme, öğrenme ve deneme yoluyla bilgi elde etmektedirler. Dijital oyunlar yoluyla gerçek hayatta karşıllaşabileceği sorunlarına cevap bulabilir, yeni fikir ve kavramları öğrenme, problem çözme ve mantık yürütme yeteneklerini uygulamaya geçirebilirler. Aynı zamanda bireylerin, dijital oyunlarda yeteneklerini keşfetme, eksik ve zayıf olgularını fark etme, strateji geliştirme, mevcut sorunlarını çözme ve karşılaşılabilecek olumsuz durumları önceden sezme gibi güdülerinin gelişmesini ve farkına varmasını sağlamaktadır. Birey, bu farkındalık ve gelişim çıktılarının, gerçek hayatta tam karşılığını bulamayabilir. Bu konu hakkında mülakattaki bir katılımcı şu ifadeleri kullanmıştır:

"Dijital oyunlar, bir kurgu üzerine kurulduğu için kimi oyunlarda gerçek olaylardan esinlenerek yapilırken kimi oyunlarda ise hayal ürünü olan olay ve kişiler üzerinden gelişmekte, buna bağh olarak birey mutlak gerçekliğin olmadığ bir oyun dünyasında sonuca kolay ulaşabilirken gerçek dünyada ise olaylar ve durumlarm eşliğinde sonuca ulaşmak zor olabiliyor. Dijital oyun dünyasında birey bir takım gelişim kazanma gösterirken bu gelişimlerin gerçek hayatta mutlak karşıllğımı olmadığım göz ardı etmemek gerekir." (Öğrenci, Erkek, 20)

Oyunların dijitalleşmesiyle birlikte geleneksel düşünce, bireylerin asosyal olduğu kanısına varmaktadır. Aslı İğit'e göre dijital oyunlar geleneksel medyanın yapmayı başaramadığı bir biçimde, sosyal birlik ve beraberliği sağlamaktadır. Bireylerin dijitalleşmeye ayak uydurmasıyla kurdukları etkileşimler ve inşa ettikleri benlikler sosyalleşmenin boyutunu, yönünü değiştirmiş ve dönüştürmüştür. $\mathrm{Bu}$ değişim ile birey sosyalleşme sınırlarını geliştirmektedir. İletişimi, mekân ve bedenin fiziki sınırları içinden çıkaran internet, bireylerin sosyalleşme pratiklerine alternatifler üretirken sosyalleşme etkinliklerini artırmaktadır. Dijital oyunlarda, özellikle çevrim içi oyunlarda ise bireylerin oyunun sonucuna varmak için diğer oyuncularla etkileşim kurmaları gerekmektedir. $\mathrm{Bu}$ şekilde bireyler birlikte oynama pratiklerini geliştirirken aralarında duygusal etkileşimler de oluşmaktadır (İgit, 2020).

Dijital oyunlarda sosyalleşme olgusuna da değinen TÜBİTAK SOBAG 107K039 projesi, dijital oyunların bireylerin asosyalleşmesi üzerinde etkinliği olduğu görüşüne eleştirel yaklaşmıştır. Araştırma projesi kapsamında varılan sonuçları özetlemek gerekirse dijital oyun ve çevrim içi platformların asosyallik sağladığını kabul 
eden kanıyı benimsemek, iletişimin sadece yüz yüze yapılan bir olgu olduğunu kabul etmek anlamına gelmektedir. Günümüzde bireylerin yüz yüze iletişimlerinin birtakım nedenlere bağlı olarak sınırlı ve kısıtlı olması beraberinde sınırları genişletme ihtiyacı doğurmuştur. Doğan bu ihtiyaç dijitalleşme ortamında karşılanırken aynı zamanda bireylerin yüz yüze iletişime kıyasla çevrim içi kanallarda kendilerini daha kolay ifade ettikleri gözlemlenmiştir.

\subsubsection{Dijital Medya Platformu Katılımı}

Klasik medya olarak bilinen radyo, televizyon ve gazete, internetin ve teknolojinin gelişmesiyle dönüşüme uğramıştır. 1990'lardan sonra gelişim sürecine giren medya, bilgisayar ve akıllı telefonların çıkmasıyla yeni medya platformlarının ortaya çıkmasına ön ayak olmuştur. Günümüzde yeni medya olarak adlandırılan dijital medya teknolojisi, zaman ve mekân kavramlarından kendini soyutladığı gibi içinde bulundurduğu içerikler ile eski medyaya oranla daha fazla kitleye hitap etmektedir.

Dijital medyanın gelişiminde önemli rol üstlenen internet; sosyal medya, dijital içerik platformları (Netflix, Amazon Prime, Exxen), canlı video yayın platformları (YouTube Live, Twitch, Facebook Live) gibi yeni medyaları bireylerin kullanımına sunarken aynı zamanda bireylerin sosyal ve kültürel gelişimini de sağlamaktadır. Bu gelişimlerin yanında medya olumsuz içeriklerin de üremesine yol açmaktadır. "Dijital medyanın bu temel özellikleri, ondan hem dünyadaki gelişmeleri takip etmek, firsatları değerlendirmek anlamında iyi karşılanmasına, hem de çoklu bilgi içinde doğru bilgiyi bulma zorluğu, yanlış kullanımlardan doğan maddi, manevi ve psikolojik sorunlardan dolayı da kötü karşılanmasına sebep olmaktadır.” (Özkan \& Hira, 2012).
Birey iradesinin ön planda olduğu dijital içerik platformlarında, tercih edilen içerikte olumsuz ögelerle karşılaşılması, kötü alışkanlıklar edinilmesi gibi durumları da ortaya çıkarmaktadır. Olumlu ögelerin tercih edilmesiyle birey; yaratıcı düşünme, problem çözme, alg1 sınırlarının gelişmesi, ilgi çekici ve sürükleyici öğrenim, eğlenceli beceri edinme gibi kazanımlar elde etmektedir.

\section{Dijital İçerik Katılımı}

İnternetle beraber bilgisayar ve akıllı telefonlar arasında oluşan ağ, geleneksel medyanın gelişmesinde rol üstlenmektedir. Yeni medyayla birlikte internet tabanlı platformlar günümüzde büyük öneme sahiptir. Tiyatro, sinema, stand-up gibi insanların sosyalleşmek için tercih ettiği mekânlardaki gösterileri içinde barındıran dijital içerik platformları kullanıcılarını mekân ve zamandan münezzeh kılmaktadır. Dijital içerik platformları arasında başarılı konumda olan Netflix'i, 2020 yılındaki verilere göre 203,7 milyon kullanıcı tercih etmektedir. Netflix'i, 150 milyon kullanıcı ile Amazon Prime Video takip etmektedir (Box Office Türkiye, 2021).

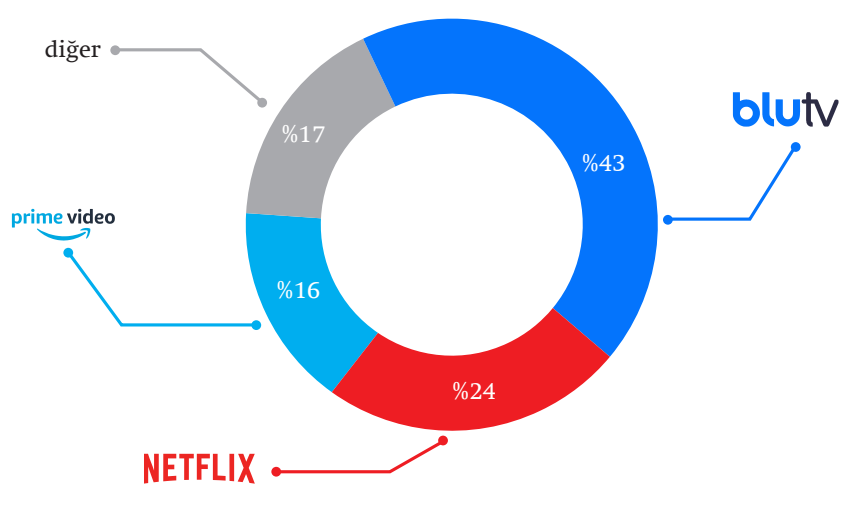

JustWatch'in yaptığı bir araştırmaya göre Türkiye'de yer alan dijital içerik platformlarının arasından Blutv \%43 oranla pazarda büyük

$\begin{array}{lll}\text { Genclik ve Sosyal Bir Literatür } & \text { TOPLUMSAL DEĞişiM }\end{array}$ 
bir yere sahiptir (Justwatch). BluTV, 2015 yllında Doğan Holding çatısı altında kurulmuş, Türkiye'nin ilk dijital içerik platformudur.

Bireyin sosyal ve kültürel gelişimi için önemli olan medyanın da dijitalleşmesiyle bireyin içeriklere ulaşması kolaylaşmıştır. Aynı zamanda mevcut içerikten faydalanacak kitle de dijitalleşmeyle beraber genişlemektedir. Örneğin bir tiyatro gösterisinde, tiyatro salonunda salonun kapasitesi kadar katılımcı sosyalleşebilmektedir. Günümüzde ise gösteriyi izlemeyi tercih eden her bireye zaman ve mekâna bağlı kalmadan dijital içerik platformları üzerinden ulaşılabilmektedir. Aynı zamanda dijital içerik platformları bireye aile ve arkadaşlarıyla içerikleri izleme ve sonrasında tartışma ortamı sunmaktadır. Birey birtakım nedenlere bağlı olarak fiziki ortamda bir araya gelemediği arkadaşlarıyla sosyalleşme ihtiyaçlarını dijital içerik platformlarından karşılamaktadır. Fiziksel olarak yan yana olmayan bireyler için geliştirilen Netflix Party uygulaması, kişiye arkadaşlarıyla birlikte film izleme ve sohbet etme imkânı tanımaktadır. Dijital içerik platformları hakkında düşüncelerini sorduğumuz bir katılımcı şunları söylemiştir:

"Birey sosyalleşmek için tercih ettiği dijital içerik platformlarında yer alan olumsuz ögeler ve kullanmayı tercih ettiği kanalın gerçeklik payının fiziki bir ortama nazaran az olmasından dolayı sağlıkı sosyalleşme zor olmaktadır. Aym zamanda bu platformda yer alan içeriklerin doğru tercih edilmesi ile birey, sosyal ve kültürel zenginlik yaşayabilir." (Öğrenci, Erkek, 18)

\section{Dijital Canlı Yayın Katılımı}

Dijital canlı yayın katılımı; bireyin internet tabanlı bir platform tarafından zaman ve mekâna bağlı olmaksızın etkileşimli bir şekilde tercih ettiği bir yayına katılım sağlayarak aktif olmasını ifade etmektedir. Bu canlı yayınlar, geleneksel medya anlayışına zıt ilerlerken interaktifliğe önem vermektedir. Yayıncının ve izleyicinin aktif olduğu bir ortamda yayın ilgi çektiği gibi katılımcının sosyalleşmesi de sağlanmaktadır.

"Yeni medya canlı yayıncılı̆ı̆ın en çekici tarafı izleyici, kullamıcı ve yayıncıların arasındaki etkileşimin en üst safhada olmasıdır. Etkileşim insanları birbirine yaklaștırıcı bir unsurdur, bu coğrafi sinırlamaları ortadan kaldırmıștır ve global bir iş modeli hâline gelmiștir. Mobil yayıncllk sayesinde sahne arkası çekimlerinden canlı konserlere, ticari fuarlardan panel ve konferanslara kadar uzanan içerik yelpazesinin yan sıra, canlı yayın muhabirliğinin tanımı ve içeriği de değişmektedir. Canlı yayı platformlarn sayesinde bireyler olağan veya anlık olaylarn anında paylaşabilirken izleyicilerden eș zamanlı olarak reaksiyon alabilmektedir ve böylece interaktif yayıncllı̆̆ tam anlamıyla deneyimleyebilmektedir." (Sahin, 2016)

\subsubsection{Video Konferans Katılımı}

"Video konferans uygulamaları sesli-görsel iletişim için doküman paylaşımı yazı, tablo ve görüntü içerme gibi özelliklere sahiptir. Video konferans, görüntü ve data iletimli ses iletişim teknolojilerinden oluşur. Ses, temel iletişim ortamı olarak kalırken, video ise görsel bir ortam sağlar." (Alkan, Tekedere, $\&$ Genc)

Geçmişte bu teknolojiyi kullanmak isteyen bireyler ses ve video ekipmanları satın alarak kullanırken günümüzde bulut tabanlı bir sistem üzerinden bilgisayar, cep telefonu ve tablet gibi cihazlarla video konferans uygulamalarına erişim sağlamaktadır.

Video konferans uygulamalarından biri olan Zoom markası, ücretsiz kullanımında 100 kişiden oluşabilen 40 dakikalık toplantılara olanak sağlarken ücretli kullanımın tercih edilmesiyle daha geniş kullanım haklarını kullanıcısına sunmaktadır. Zoom, \%40,49 oranla pazar payına sahip olmakla beraber 2020 yılının ilk çeyreğinde günlük ortalama 200 milyon aktif kullanıcıya ulaşmaktadır. Günümüzde eğitim, askerî, kamu ve özel sektörde yaygın kullanılan 
video konferans sektörünün gelecek yıllarda sağlık sektöründe de yaygın kullanılması beklenmektedir (Nolto).

Covid-19 salgın süreciyle önem kazanan video konferans uygulamaları, bireyin iş ve eğitim hayatında meydana gelebilecek sınırları ve sorunları ortadan kaldırıp sürdürülebilir iletişim kurmalarına imkân sağlamaktadır. Bunun yanında bireyin arkadaşlarıyla muhabbet etmesi, birtakım online etkinliklere katılması, olası afet ve acil durum yönetimi gibi durumlarda canlı konferans sistemleri önem arz etmektedir.

İnsanların etkili bir şekilde ve mekânı ortadan kaldırarak kullanmayı tercih ettikleri bu platformlar bireyin zamanını verimli kullanmasını sağlarken katılım sağladığı programlarla bireyin sosyal statüsünü de geliştirmesine olanak sağlamaktadır. Örneğin tercih edilen platformlar aracılığıyla oluşturulan webinar, etkileşimli oyun oynama, online konser ve etkinlik gibi organizasyonlara katılım sağlayan kişi dijital ortamda sosyalleşmektedirler.

Video konferans uygulamalarının bireyin hayatında oluşturduğu avantajlar gibi birtakım dezavantajlarının da olması beklenmektedir. El sıkışma, sarılma, göz teması kurma, beden dili gibi iletişimi güçlendiren unsurların oluşmasında eksik kalan bu uygulamalar iletişim anında algılama, anlamlandırma ve ifade etme gibi durumların zorlaşmasına yol açabilmektedir. Aynı zamanda uygulamalı eğitim modellerinde yapılması gereken deney ve gözlemlerin yapılması hususunda eksik kalmaktadır. Teknik ve yapısal sorunlar, yazılımda meydana gelen sıkıntılar, erişim problemi, ekipmana ulaşım zorluğu gibi sorunların varlığı iletişimin oluşmasına engel olmaktadır. Video konferans uygulamalarında başlıca sorun olarak görülen ve iletişimi tehdit eden diğer bir unsur ise siber saldırılardır. Bireyler arasında iletişimin mahremiyetine zarar verebilecek bu unsur, iletişimin aksamasına yol açabildiği gibi iletişim anındaki konuşmaların ve belgelerin çalınmasına da neden olabilmektedir (Netinbag.com).

\subsection{Devamlılık ve Motivasyon}

Herhangibir maddibeklenti içindeolmadan kendi istekleriyle sosyal faaliyetlere katılan kişiler gönüllü, bu faaliyetler ise gönüllülük faaliyetleri olarak adlandırılır. Sosyal katılım konusunda önemli hususlardan birisi de gönüllülüğün devamlılığıdır. Atölyede yapılan mülakatlarda bir üniversite öğrencisi (Öğrenci, Erkek, 23) gönüllülük faaliyetlerinde yer alan kişilerin devamlılık ile ilişkili olarak iki gruba ayrılabileceğini iddia etmiştir. Kısa süreli katılım gösteren kişileri "katılımcı” olarak adlandırırken ancak sürekliliği sağlayanların "gönüllü” olarak isimlendirilebileceğini söylemiştir. Bir kişinin katılımcı olarak kalmasını veya gönüllü olarak devam etmesini belirleyen etkenlerin başında ise aktiflik ve işe yarama hissinin olduğu gözlemini paylaşmıştır. Bu durumda kişiler işe yaradıklarını ve ihtiyaç duyulduklarını düşündükleri ortama daha fazla aidiyet beslemekte ve katılımı sürdürmektedir.

Bir katılımcıyı gönüllülü̈̆ge taşıyan motivasyonları ve gönüllüllük niyetini katılımcılık ile sınırlandıran faktörleri daha geniş çapta değerlendirmek gerekirse, birkaç konu odağında geçmişten günümüze gönüllülükte sürekliliği sağlayan motivasyonların değişimi ele alınabilir.

Öncelikle gönüllülük, temelde özgecilik teorilerine dayandırılıp gönüllü olmanın en büyük motivasyonunun ise insanlara yardım etme düşüncesi olduğu söylense de yeni çalışmaların özgeciliğin yanına sosyal temas, kişisel ilgi alanları, duygusal güdüler gibi birçok madde eklediği görülmektedir (Yeung, 2004). Yapılan çalışmalar rol kimliğinin pozitif gelişimi, kişisel tatmin, topluluk duygusu, akran desteği, sağlanan eğitim ortamı, gönüllülük 
ortamı ve gönüllülerle kalıcı ilişki geliştirilmesi gibi faktörlerin de sürekliliğe katkı sağladığını göstermiştir (Erdoğmuş ve diğerleri, 2020). Walter Rehberg (2005), özgeciliğe dayalı katılımı daha çok "eski katılımcılık” olarak değerlendirmiştir. Katılımcılığın "eski gönüllüllük” formundan "yeni gönüllülük” formuna doğru bir değişim geçirdiği konusunda mutabakat olduğunu iddia eden Rehberg (2005) "yeni gönüllülük" formunun ise daha proje odaklı olup gönüllülerin katılımlarının zamanı, içeriği ve formu üzerinde spesifik beklentilerinin olduğu bir gönüllülük formu olduğunu söylemiştir. Hustinx (2001) uluslararası çalışma kamplarına katılan genç gönüllülerin bu "yeni katılım” formunu destekleyici şekilde, özellikle organizasyonlara sadık olmadıklarını, yapacakları şeyi seçmeye eğilimli olduklarını ve gönüllülük faaliyetlerinden kişisel çıkar beklediklerini belirtmiştir. Yapılan çalışmada genç gönüllülerin kamplara katılmadaki gönüllülüik motivasyonlarını "başkaları için pozitif bir şey elde etme”, "yenilik arayışı", "kendilik arayışı" şeklinde 3 grupta toplamıştır. Dinî ve politik topluluklar gibi belirli bir sosyal çevreyle ilişkili, uzun süreli ve çoğunlukla üyelik merkezli taahhüt isteyen eski gönüllülük formunun (Rehberg, 2005) aksine, yeni gönüllülük modelinin Türkiye'deki tezahürü de benzer şekilde olmuştur. Kurumsal Yönetim Akademisi Raporu (2020) da yaptığı araştırma sonucunda gönüllülerin nedenlerini gönüllülüğe yüklenen olumlu anlam, çıkar beklemeden başkalarına faydalı olmak, insan olmanın ve hayatın amacı olması, topluma katkı sağlamak, gündelik rutinden çıkmak ve yeni bir şeyler yapmak olarak bulmuştur.

Eski katılım modelinde daha çok topluma fayda amacıyla gerçekleştirilen katılım, günümüzde yerine birçok kişisel fayda motivasyonu eklemiştir. 2019 yılında gençlik merkezleri örneği üzerinden gençlerin katılım motivasyonunu inceleyen raporda en yüksek orandaki motivasyon yeni yetenekler kazanmak veya yetenek geliştirmek olarak bulunmuştur. Sosyal iletişim kurma, kendini gerçekleştirme ve takdir edilme gibi motivasyonlar da bulgular arasında yer almıştır. Erdoğmuş ve diğerlerinin (2020) raporunda belirttiği üzere meslek ve kariyer gelişimine katkı, gönüllülük motivasyonlarından biridir. Fakatyapılan görüşmelerde gönüllü olunan kuruluşlara güven duymakta zorlanmanın bu motivasyonda bir değişikliğe sebep olduğu görülmüsstür. Bu ve bu gibi katılımı zorlaştıran faktörler kısmında bahsedilecek olan motivasyon düşüklükleri katılım tercihlerini de etkilemiştir. Bunun yerine daha bireysel alanlara yönelen katılımcılar, yeni sosyal katılım formları olan sosyal medya katılımlarını bahsedilen takdir edilme, sosyal iletişim kurma gibi motivasyonlardan bir kısmını karşılamada yeterli görmüştür.

Bu bilgilerden hareketle katılımcı tarafindan farklı bir kategoriye konulan tek seferli katılımcılık, gönüllülüğe ulaşamayan bir başarısızlık değil aksine yeni bir gönüllülük formu olarak görülebilir. Mülakatlarda yer alan bir üniversite öğrencisi tek seferli katılımın da çok önemli olduğunu, gençler için bir yerde iz bırakmayı ifade ettiğini söylemiştir (Öğrenci, Kadın, 23). Bir diğer üniversite öğrencisi ise dönemin gençleri için bu gönüllülü̈k formundaki değişimi bir gereklilik olarak gördüğünü şu sözlerle ifade etmiştir: "Dönemi, gençlere uyarlamak çok önemli burada. Jenerasyon ve zaman, imkanları artırmaya yönelik çalışmalara muhtaç. Gençlik bir öncekini taklit istemiyor. Sürekli değişim istiyor. Geliştirmeye açık projeler bekliyor.” (Öğrenci, Erkek, 22).

Tek seferli katılımlara dâhil olabilecek bir kategori olarak mülakatta yer alan katılımcılardan biri (Erkek, 26) pragmatik katılım diye bir kategoriden de bahsetmiştir. Bu katılım şekli CV doldurma, bu sayede $A B$ projeleri yapabilme, yüksek lisansa kabul alabilme gibi motivasyonlarla, network içinde kendini var etme arzusuyla gerçekleşebilmektedir. Gönüllülük motivasyonunun sadece manevi ihtiyaç ve hedeflerden oluşmadığını, gönüllüllüğün eğitime katkısının da maddi beklenti kategorisine girdiğini düşünen bir katılımcı da 
"Gençler gönüllüllük işlerinden eğitimlerine katkı sağlamalarını da bekliyor. CV’de bulunması gibi de düşünülebilir, kişisel gelişim gibi de.” (Öğrenci, Kadın, 23) sözleri ile yeni bir beklenti çeşidini dile getirmiştir.

Kişiler açısından yapılan tek seferli veya sürekli katılım ayrımı projeler için de söz konusudur. Kişilerin gönüllülüğü sürdürebilmesinin yanında projelerin de sürdürülebilirliği önemlidir. Kimi çalışmalar yıllarca aynı sistemle devam ederken kimisi birkaç seferde farklı sebeplerle sona ermektedir. Sürdürülebilirlik konusunda mültecilerin entegrasyonuna yönelik bir derneğin başkanı olan bir katılımcı 2015’ten bu yana yaptıkları projelerin sürdürülmesi ve dernekleşmesini "gemi modeli" dedikleri ekip yönetim ve uygulama alana bağlamıştır:

"Organizasyonu mürettebat mantığıyla idare etme usulü, sürekliliği de temellendirmis oldu. Organize eden ve sahadaki uygulayan aym derdin farklı ekipleri oldular. Kaptanların, gönüllülerle iş bölümü yaptıkları ve herkesin sahaya dahil olduğu bir iş bölümüyle projelerin ve gönüllülerin devamın sağladılar." (Dernek Başkanı, Erkek, 25)

Üniversite öğrencisi katılımcılardan bir diğeri de gönüllülüğe eğer kendisine ihtiyaç olduğunu düşünürse devam ettiğini söylemiş ve eklemiştir:

"Gençler aktif olup kendilerine söz hakkı verilen ve dikkate alnan işlere meylediyor, artık aktif katılım istiyorlar. Geleyim de onlar anlatsin ben dinleyip gideyim demiyorlar. Eğitimini aldım artık sahaya ineyim diyorlar. İste okul boyayalım, sokaklarda olalım diyorlar. Aktif olarak sahada varlı gösterelim diyorlar. Gençleri etken yapıp sahaya indirmek gerek." (Öğrenci, Erkek, 22)

Sürekliliği sağlayan motivasyon konusunda benzer bir yorumu diğer üniversite öğrencisinden de duymak mümkündür:
"Sosyal işlerde gönüllülük-gönül verme varsa süreklilik de oluyor. Gençlere 'Ben burada olmazsam bu iş eksik kalır' düşüncesini verebiliyorsanz o işte sürekliliğe kavuşuyorsunuz. Sürekliliği kendiliğinden işler hâle getiriyorsunuz." (Öğrenci, Kadın, 23)

Mülakat esnasında, bir katılımcıyı aktif katılımcı yapan şeyin ise ona sen burada bir şey yapabilirsin demenin ve görev vermenin olduğu söylenmiştir. Bu ifadelerle gençlerin sahada aktif olma ve ihtiyaç duyulma ihtiyacı açıkça ortaya çıkmıştır. $\mathrm{Bu}$ ihtiyaç karşılandığında ise faaliyetlere motive oldukları ve sürdürülebilirliği sağladıkları görülmüştür. Pandemi dolayısıyla değişen toplantı platformları göz önüne alındığında da bu motivasyona dair fikir edinilebileceği görülmüştür. Katılımcılardan biri (Öğrenci, Erkek, 22), gençlerin Zoom üzerinden yapılan toplantılarda seslerini açıp konuşabildikleri için ve bu mecra katılıma daha açık olduğu için Youtube gibi nispeten sessiz yerlerdense Zoom gibi platformları tercih ettiklerini belirtmiştir.

Gönüllülüğün sürdürülebilirliğini sağlayan etkenlerden bir diğeri de çevre etkisidir. Arkadaşları arasında yaptığı çalışmaları takdir edilen ve birlikte katılım gösterebilen gönüllüler daha uzun yıllar bu faaliyetleri sürdürmektedir. Üniversite başlangıcından itibaren bir arkadaş grubu olarak başlatılan ve sonrasında dernekleşme sürecine kadar giden mülteci çocuklara yönelik çalışmaları üzerine konuştuğumuz 3 katılımcı ile yapılan mülakatta bu gibi işlerde bir arada ve ayakta kalabilmenin “dert ortaklığı” ve ortak kaygılar sayesinde olduğu belirtilmiştir. Üniversite kulüplerinde yer alan bir katılımcı ise "Arkadaş ortamında kabul gören bir yaklaşım olmadığında da gönüllülük motivasyonu kalmamış oluyor.” (Öğrenci, Kadın, 23) cümlesiyle arkadaş ortamının gönüllülükte ne kadar büyük bir rol oynadığına dikkat çekmiştir.
Genclik ve Sosyal Bir Literatür

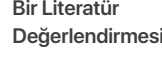


Özetle farklı motivasyonlara dayanan gönüllülük tecrübesi, zamanla değişime uğramakta ve yeni formlara girmektedir. Yeni katılım formu ile karşılaştırıldığında kuruma daha bağlı, sürekli ve topluluk hâlinde gerçekleşen eski katılımcılık formu gençler tarafindan tercih edilmemekte ve daha dinamik olan yeni katılım motivasyonları geliştirilmektedir. Bu yüzden aktif, proje bazlı veya kişinin kendisinin yönetmek istediği katılım türleri ve bu sebepten ötürü kısa süreli katılımlar süreklilik ve gönüllülük açısından başarısız kabul edilmemeli, çeşitlilik kabul edilmelidir. Sosyal katılımda bu değişimi destekleyecek yeniliklerle daha aktif katılıma ve sürdürülebilir katılımcılığa yol açılmalıdır. Mülakatlardan ve literatürden yola çıkılarak arkadaş faktörü kurumlar tarafindan motivasyon artırıcı bir etken olarak kullanılabilir. Değişen katılım formuyla gençlerin toplumsal faydadan bireysel faydaya yönelişi dikkate alınarak toplumsal ve bireysel fayda dengesini koruyabilecek ve bu sayede gençleri sosyal katılımdan uzaklaştırmayıp katılımdan beklentilerini karşılayarak onları sahada tutabilecek iki fayda arasında dengeyi sağlayabilecek bir form oluşturulabilir.

\subsection{Liderlik}

Liderlik, tarihsel süreç içerisinde toplumlar için önemli roller üstlenmiştir. Bu nedenle farklı bilim alanlarında çalışmalara konu olmuştur. Bu çalışmalar neticesinde çok sayıda liderlik tanımı ortaya çıkmıştır (Bakan \& Büyükbeşe, 2010). Bu tanımlardan yola çıkarak liderliği genel bir ifadeyle tanımlayacak olursak "bireyleri belli bir amaç etrafinda toplayabilme, bir amaca yönlendirme, hitap ettiği insanları ikna edebilme becerilerine sahip olma ve insanları motive edebilme yeteneği” (Öztürk \& Emli, 2017: 99) olarak ifade edebiliriz. Örgüt veya gruplar için liderlik; belirlenen amaçlar doğrultusunda doğru tercihlerde bulunma, onları güçlü şekilde temsil etme ve başarıya ulaşma noktasında gerekli şartları sağlamada önemli bir konuma sahiptir (Altan \& Özpehlivan, 2019).
Liderlik kavramı üzerinde uzlaşılan tek bir tanım olmadığı gibi her örgüt veya grup için geçerli tek tip liderlik tarzı da bulunmamaktadır. Liderlik tarzı içinde bulunulan çevresel şartlara, liderlik sürecine ve liderlik yapan kişinin özelliklerine göre değişebilmektedir (Bakan \& Büyükbeşe, 2010). Dolayısıyla sivil toplum kuruluşlarındaki liderlikle kâr amacı güden herhangi bir örgüt veya gruptaki liderlik birbirinden farklıdır çünkü sivil toplum kuruluşları sosyal amaçlar doğrultusunda bir araya gelen gönüllü insanlardan oluşmaktadır (Bunchapattanasakda et al., 2012). Sivil toplum kurulışları da tıpkı diğer kuruluşlar gibi örgütlenme, yönetim, planlama ve denetim mekanizmalarına ihtiyaç duymaktadır. Aynı zamanda verimlilik, etkililik, kaynakların doğru kullanılması, yeni kaynaklar yaratma gibi hedeflere de sahiptir (Yılmaz \& Akdeniz, 2020). Bu nedenle toplumlar için önem taşıyan sivil toplum kuruluşlarında liderlik, başarı için kilit bir kavram olarak karşımıza çıkmaktadır (McMurray et al., 2012). Nitekim Kılınç (2019) yapmış olduğu çalışmada sivil toplum kuruluşları için liderliğin önemini şu şekilde ifade etmiştir:

"Liderlik, sivil toplum kuruluşları başarısının vazgeçilmez bir parçasıdır ve kuruluşun tüm seviyelerinde uygulandığında en büyük etkiye sahiptir. Bu kurumlarda liderlik, geleneksel 'ast/üst' ilişkinin ötesine geçer. Otoriteye sahip olmadan liderlik etmek, bir kuruluştaki lider kişiliğin resmî konumundan elde edilen kuvvete değil; insanlarn değerlendirip geliștirmeye ve toplumu inşa etmeye dayandığından ayrıca önemlidir. Bu anlamda sivil toplum kuruluşlarının gönüllülük felsefesi çerçevesinde oluşturduklarn ve diğer sektörlerden onu ayıran gönüllülük unsuru yönetim süreçlerinde de ön plana çıkmaktadır.” (Kılınç, 2019: 1103)

Küreselleşme süreciyle birlikte liderden beklentiler de değişime uğramıştır. Özellikle değişen çevresel koşullar ve gelişen teknolojinin etkisiyle artan bilgi düzeyi liderlikten beklentileri değiştirmiş ve dönüşüme uğratmıştır (Kılınç, 2019). Bilgi düzeyinin artması ve kültür düzeyinin yükselmesi bireylerin yönetimde 
etkin rol almak istemelerine ve başkaları tarafindan yönetilen bir nesne olmak istemedikleri durumunu ortaya çıkarmıștır (Öztürk \& Emli, 2017). Bu durum aslında günümüz insanının karakteristik özelliğini de ortaya koymaktadır. Modern dönemle birlikte değişen benlik algısı geleneksel tanımlamaların dışında, kendine dönüşü esas alan yeni bir yaklaşıma dönüşmüştür (Taylor, 2001). Bu bağlamda başta gençler olmak üzere günümüz insanını tanımlayacak olursak, post-modern insan hayatın her alanında özne olmayı, kendi kurallarını ve sınırlarını belirlemeyi, özgür ve spontane olmayı seçen ve herhangi bir şeye bağlı olmadan kendi yaşamını kendisi belirlemeye çalışan bir karaktere sahiptir. Bu tip karakter için en önemli olay, sınırlarını kendisinin belirlediği benodaklı bir dünyanın üretilmesinden duyduğu hazdır. Post-modern insanın temel inancını, "ancak kendi kendinden bir şey yaratırsan, bir şeysin demektir” (Funk, 2020) anlayışı oluşturur.

Hızlı değişim ve dönüşümlerin yaşandığı ve insanların daha bilinçli olduğu günümüz dünyasında örgütsel yapıların var olabilmeleri için dönüşümcü ve insan odaklı liderlik anlayışına sahip olan liderlere sahip olmaları zorunlu hâle gelmiştir (Tengilimoğlu, 2005). Dolayısıyla literatürde var olan çeşitli liderlik teorileri değerlendirildiğinde sivil toplum kuruluşları içinde en uygun liderlik türü olarak dönüşümcü liderlik tarzı öne çıkmaktadır. Liderin etkili sonuçlar üretebilmesi için vizyon sahibi, değişim öznesi ve stratejist olması gerekmektedir. Bununla birlikte sivil toplum kuruluşu üyeleri tutku ve vizyonlarını geliştirmek için kendilerine rol model olacak ve otoriter olmayan bir lidere ihtiyaç duymaktadırlar (Koo et al., 2017). Bu nedenle modern organizasyonlarda yeni alanların yaratılması konusunda en uygun ortamı dönüşümcü liderlik sağlamaktadır (Eraslan, 2005).

Dönüşümcü liderlikte lider, takipçilerinden beklenenin üzerinde performans göstermesi için üyeleri motive eder ve takipçilerine vizyon kazandırma konusunda oldukça başarılı rol oynar (Bass, 1999). Aynı zamanda bu tarz liderler geleceğe yönelik, dinamik, planlı ve açık fikirlidir. Dolayısıyla yeniliği teşvik etmede ideal bir tarz olarak karşımıza çıkmaktadır (Jaskyte, 2004). Dönüşümcü liderlik takipçilerine araştırma, sorgulama, tartışma ve kendi kararlarını alabilme gibi özgürlük alanları tanır. Bu tarzda ortaya konan bir liderlik sağlıklı bir çalışma ortamı yaratır. Böylece liderlik örgüt içinde bireyler arası karşılıklı anlayışı, açık fikir alışverişini ve analitik bakış açısını geliştirerek örgüt üyelerinin öz-yönetim ya da öz-liderlik becerilerinin gelişimine katkı sağlamış olur (Aga et al., 2016).

Bass ve Avolio (1994) dönüşümcü liderliği tanımlarken dört önemli boyuta değinmişlerdir. Bunlar; açıklık, esin, destekleyici ve takım kurma olarak ifade edilmektedir. Bu kavramlar dönüşümcü liderliğin; takipçilerin amaçlar doğrultusunda bilgilendirilmesi ve gizliliğe yer verilmemesi, iş birliği için tekliflerle birlikte şikâyetleri değerlendirme, arkadaşça davranmak, ilgili ve sabırlı olmak, iş birliğini teşvik etmek gibi özelliklerini ifade etmektedir (Kantos, 2011). Nitekim araştırma sürecinde görüşme gerçekleştirdiğimiz bir sivil toplum yetkilisi, mültecilerle ilgili yapmış oldukları çalışmadan bir örnek vererek lider ve takipçileri arasındaki ilişkiye değinmiş ve uygulamış oldukları sistemi şu şekilde ifade etmiştir:

“Organizasyonu mürettebat mantığyyla idare etme usulü sürekliliği de temellendirmiş oldu. 2015’ten 2017'ye kadar usulen ‘Gemi Modeli’ üzerinden ilerledik. Sürdürülebilirlik burada etkili oldu. Mürettebat dediğimiz ekip yönetim ve uygulama alaniydı. Organize eden ve sahadaki uygulayan aym derdin farklı ekipleri oldular. Kaptanlar, gönüllülere iş bölümü yaptılar ve herkes sahaya dâhil oldu. Herkesin sorumluluğu belli ve ekip işiyle her is doğal olarak hallediliyor. Projeler bittikten sonra geri dönüş alyoruz herkesten. Sonuçları da ekiple tartışıoruz; bir nevi kendimize öğretiyoruz." (Avukat, Erkek, 27) 
Katılımcının gemi ve mürettebat üzerinden ifade ettiği çalışma tarzı tam olarak bir ekip çalışmasını ifade etmektedir. Bu sistemde liderin sorumluluk aldığı ve aynı amaç doğrultusunda lider dâhil herkesin aktif olarak sorumluluklarını yerine getirdiği bir mekanizma oluşturulmuştur. Aynı zamanda herkes kendi sorumluluğunda olan işi bir lider gibi yerine getirmektedir. Böylece bireyler hem öz güven ve öz yönetim anlamında gelişim sağlamakta hem de gönüllü olarak almış oldukları görevleri başarmak için arzuyla eylemlerini sergilemektedirler. Bunun yanı sıra bir diğer önemli nokta da katılımcıların birer nesne olmaktan ziyade özne olarak çalışmalarda yer aldıklarının görülmesidir. Dolayısıyla bu tip bir organizasyonda bireylerin bilgi ve becerilerini bağımsız bir şekilde uyguladıkları bir ortam oluşturulduğu görülmektedir. Diğer bir ifadeyle katılımcı bireylere, özellikle de gençlere, kendi yaptıkları işte lider olma imkânı tanınmaktadır.

Kurum ya da kuruluşlarda görev alan gençlerin yalnızca katılımcı olarak değil aynı zamanda yönetici ya da lider olarak da görev alabiliyor olması onlar açısından önemli bir motivasyon kaynağı olabilmektedir. Bu bağlamda gençlerin sahip oldukları liderlik özelliklerini de değerlendirmek ve onlara yol açmak katılım açısından da büyük önem arz etmektedir. Gençlerin sahip olduğu liderlik potansiyelini bilişsel işleyiş (cognitive functioning) ve duygusal işleyiş(affective functioning) olmaküzereikiye ayırabiliriz. Bilişsel işleyiş özellikleri arasında yüksek enerji ve motivasyon, devamlılık, büyük miktarda bilgiyi işleme ve tutma, hedefi gerçekleştirmek için görevleri sıralama, karmaşık ve zorlu işlerde tercihte bulunabilme ve güçlü iletişim özellikleri yer almaktadır. Duygusal işleyiş özellikleri arasında ise esneklik, ötekilere yönelik hassasiyet, sorumlu olma isteği, çeşitli insanlarla iyi anlaşabilme, yüksek öz farkındalık ve kendinden ve başkalarından yüksek beklenti gibi özellikler yer almaktadır (Manning, 2005). Gençlerin liderlik yapıyor olması aynı zamanda gençlere söz hakkı verilmesi, gençlerin katılımı, gençlere karar hakkı tanınması ve gençlerin güçlendirilmesi gibi anlamlar taşımaktadır (Cansoy \& Turan, 2016).

\subsection{Sosyal Sermaye Olarak Sivil Katılım}

\subsubsection{Sosyal Sermaye}

Son dönemlerde sosyal teoride, modern toplumla beraber yalnızlaşan bireyin maruz kaldığı anomi ve yabancılaşma sorunlarına karşı, panzehir olarak bir arada eylemde bulunmanın, topluluk olmanın ve karşılıklı ilişkilerin önemine dikkat çekilmeye başlanması, sosyal sermaye kavramının ortaya çıkmasında etkili olmuştur. Böylelikle, modern dönemin önemsemediği, dışladığ1 ve küçümsediği geleneksel değerler, ilişsiler ve ağlar modernliğin sorunlarına fonksiyonel çözümler sunacak bir kaynak olarak ele alınmaya başlamıştır (Aslan, 2012). Sosyal sermayeyi, toplumu oluşturan bireyler, sivil toplum örgütleri ve kamu kurumları arasındaki uyum faaliyetlerini kolaylaştırarak toplumun üretkenliğini artıran normlar, iletişim ağları ve güven olarak tanımlamak mümkündür (Dündar, 2006).

Sosyal sermaye kavramını ilk kez Hanifan (1916) kullanmıştır. Hanifan'a göre bu kavram, özel mülkiyet ve para gibi somut şeylerin dışında insan ilişkileri ve bireylerin günlük yaşamda geliştirmiş oldukları iyi niyet, arkadaşlık, yakınlık gibi ilişkileri tanımlamak için kullanılmıştır (Çalışkan, 2010: 5-6). Daha sonra sosyal sermaye kavramını, Bourdieu, Coleman, Portes ve Putnam çalışmaları ile geliştirmişlerdir.

Sosyal sermaye kavramı çok farklı bilim dalları tarafından farklı şekillerde tanımlanmıştır. Bunun nedeni farklı disiplinlerin farklı hedefler doğrultusunda kavramı kullanmasıdır. Kavramın çok boyutlu olmasından dolayı, hemfikir olunan tek ve net bir tanım bulunmamaktadır. Fakat yine de kavramın üzerinde en fazla fikir 
birliğiolan tarif; güven, normlarveiletişim kavramlarıylayapılandır (Dündar, 2006). Literatürde genel olarak sosyal sermayenin; güven (trust), karşılıklılık (reciprocity), ağlar (networks), birlikler (associations), birlik veya grup üyeliği, normlar ve ortak (collective) faaliyet kavramlarına dayalı olarak tanımlandığı görülmektedir (Yavuz, 2012).

Sosyal sermaye kavramının en çok atıfı Amerikalı bir siyaset bilimci olan Robert D. Putnam'a aittir. Sosyal sermaye kavramı Putnam nedeniyle daha geniş bir alana yayılmış 1990'larda sosyal bilimlerde en fazla alıntılanan yazar olarak kabul edilmiştir. Putnam'a göre sosyal sermaye, "sosyal hayatın belli bir ortak hedef doğrultusunda birlikte davranabilmesini sağlayan ağlar, ilişkiler, normlar ve güven gibi özellikler"dir (Yllmaz, 2015).

Bir topluluk duygusunun nasıl oluştuğunu anlamak, toplum için önemlidir. Toplumları ve kuruluşları başarılı ve iş birlikçi yapan sosyal sermayedir. Sosyal sermayesi yüksek olan toplumların daha gelişmiş ve daha fazla kaynağa sahip olduğu, güçlü pozisyonlardaki kişilerle tanışıklık sebebiyle iş bulma, kariyer geliştirme, suçun ve sağlık problemlerinin azaltılması, eğitimde başarının artması ve buna benzer sosyal hayata dair birçok sorunun çözümünde sosyal sermayenin çok önemli olduğu düşünülmektedir. Bu nedenle Putnam (1993) sivil toplumu sosyal sermaye ve toplumsal kalkınma bağlamında ele almış ve yaptığı durum tespiti ile sosyal sermayeye olan ilgiyi daha da artırmıştır (GÖK, 2015).

Robert Putnam, "Tek Başına Bowling (Bowling Alone, 2000)" çalışmasında genel toplum üzerine yoğunlaşmakta ve topluluk duygusundaki azalmaya dikkat çekmekte bu doğrultuda tek bir soruya yanıt vermeye çalışmaktadır: "Ülkelerin ekonomik ve siyasi performanslarıyla sivil faaliyetleri arasında nasıl bir ilişki vardır?" Eserinde, kişiler arası güveni oy kullanım oranının, klasik cemiyetlere üyeliğin ve politik veya toplumsal eylemlere katılımların düştüğünü öne sürer (Özcan, 2011). Teknolojik gelişmeye ve yeni medyaya rağmen ve aslında onlar yüzünden günümüzde insanlar her zamankinden daha az ilişki içindedir. Bu değişimin nasıl meydana geldiğini Putnam, bowling örneğiyle açıklamaktadır. Bir dizi anketten elde etmiş olduğu verileri kullanarak Amerika'da son otuz - kırk yıldır insanların izole hâle geldiğini, artık kulüp ve derneklere ait olmadıklarını, birlikte bir şeyler yapmadıklarını ama bunun yerine tek başlarına bowling oynamaya devam ettiklerini tespit etmiş ve bu bağlamda sosyal sermayenin erozyona uğradığını gözler önüne sermiştir. Ona göre, sivil toplum kuruluşlarına katılım oranları arttıkça sosyal sermaye de artmaktadır. Bu açıdan Amerika'da sosyal ve ikincil organizasyonların sivil katılım oranlarının gittikçe düştüğünü gören Putnam, Amerikalıların sosyal ağlara katılımının fark edilecek derecede azaldığını ve buna paralel olarak vatandaşların birbirlerine olan güvenlerinde de azalma olduğunu savunmaktadır.

Putnamci anlamda sosyal sermayenin temel ögeleri güven, karş1lıklılığa dayanan norm ve yükümlülükler ve son olarak da vatandaşların dâhil olduğu sosyal ağlardır. Amerikalıların sosyal ağlara katılımlarında fark edilecek derecede azalmanın arkasındaki sebepler Putnam'a göre değișen aile yapısı, kadınların iş hayatına dâhil olmalarıyla beraber örgütlü yaşama katılımlarında azalma, boşanmalar, tek ebeveynli ailelerin çokluğuna bağlı olarak aile yaşamında çözülmeler, mekânsal bütünlüğü kıran yüz yüze olmayan çevrim içi faaliyetler sonucunda "bireyselleşme" ve “özelleşme”dir. Ona göre, temel neden ne olursa olsun, yavaş yavaş sosyal dünyayı aşındırdığımızı savunmaktadır. 


\subsubsection{Sosyal Sermaye Türleri}

Sosyal sermayenin bütün biçimleri ele alındığında Putnam için iki ayrım önemlidir: bağlayıcı (bonding) sermaye ve köprü (bridging) oluşturan sermaye. Bu şekilde bir ayrım Putnam (2000) tarafından ilk defa yapılmıștır. Genel olarak ya bağ kuran ya da köprü kuran sosyal sermaye, bir sosyal ilişkinin doğasını tanımlar. İlişki benim gibi benzer sosyal çevrelerde hareket eden biriyle ise o zaman bağ olarak tanımlanır. İlişki benden farklı farklı çevrelerde hareket eden biriyle ise köprü kuran sosyal sermaye olarak tanımlanır. Sosyal ilişkiler çok daha karmaşıktır ve tipik olarak bir ilişki bazı bağlanma özelliklerine ve bazı köprüleme özelliklerine sahip olacaktır (Claridge, 2018).

\section{Bağlayıcı Sosyal Sermaye}

Bağlayıcı (Bonding) sosyal sermaye, "birlikte olan" ve tipik olarak güçlü yakın ilişkileri olan "bizim gibi insanlar" arasında mevcuttur (Claridge, 2018). Aile üyeleri, yakın arkadaşlar, komşular şeklinde birbirine yakın kişiler arasındaki ilişkilere işaret etmektedir. $\mathrm{Bu}$ sermaye türü bireyleri birbirine bağlamakta, maddi ve duygusal destek sağlamakta, daha içe dönük ve koruyucu yapmaktadır. Bireyler bu sayede birbirleriyle çok fazla temas hâlindedirler ve bu temaslar ortak davranıs normlarını ve bireylerin birbirlerine karşı beklentilerinin oluşmasını sağlamaktadır (Başak ve Öztaş, 2010). Sosyal sermayenin bağlayıcı yapısı; yaş, eğitim, etnik yapı, ekonomik ya da politik görüş gibi bir veya daha fazla özelliğin benzeşmesidir. Bağlayıcı sosyal sermaye, insanların "idare etmesine" yardımcı olma eğilimindedir ve iş birliğine dayalı eylemi kolaylaştıran normları ve güveni sağlar (Claridge, 2018).

Bağlayıcı sosyal sermayenin koruyucu doğası nedeniyle olumsuz sonuçlara sahip olma olasılı̆ıı yüksektir ancak aynı zamanda çok önemli bir sosyal destek kaynağıdır. Aşırı düzeyde bağa sahip ağlar; ön yargı ve ırkçılığı üretme, dış gruplar ve dışlanma eğilimindedir. 1865'te ABD'de kurulan Ku Klux Klan; siyahi karşııtı, beyaz üstünlükçüsü, göçmen karşıtı, gizli bir örgüt, genellikle olumsuz sonuçları olan yüksek düzeyde bağlanan sosyal sermayeye bağlı bir grubun örneği olarak gösterilmektedir (Claridge, 2018).

\section{Köprü Oluşturan Sosyal Sermaye}

Köprü (bridging) oluşturan sosyal sermaye, genellikle ortak ilgi alanları veya hedefleri olan ancak sosyal kimliği zıt olan insanlar arasındaki ilişkilerden oluşan sosyal değişim ilişkilerini tanımlar (Pelling ve Yüksek 2005). Köprü (bridging), bağlayıcı sosyal ağların aksine, yatay bir metafor olup birçok benzer demografik karakteristiği paylaşan ama birbirine çok yakın olmayan kişiler arasındaki ilişkiye işaret etmektedir. İs birlikleri, tanışıklık, farklı etnik gruplardan edinilen arkadaşlıklar, arkadaşların arkadaşları gibi daha zayıf ve daha az yoğun ama daha çeşitli ve çapraz kesişen sosyal bağlardan türemekte ve insanları kendilerinden çok farklı bir döngüde hareket eden daha uzaktaki tanıdıklara bağlamaktadır (Eşki, 2009). Köprü oluşturan sosyal ağlarda, belirli bir toplumsal kimlik paylaşılmamakta ve benzer toplumsal kökene ya da statüye sahip olmak ağın bir parçası olmada bir ölçüt olmaktan çıkmaktadır (Başak ve Öztaş, 2010).

Köprü kuran sosyal sermayenin faydaları çok geniştir; daha fazla bilgi toplama yeteneği, iktidara erişim, yeni firsatları daha iyi fark etme becerisini içermektedir (Adler ve Kwon 2002). Sosyal sermayeyle sosyal sinırlar aşıldığından, farklı insanlarla, değerlerle ve inançlarla beraber hoşgörü artmaktadır (Paxton 2002). Sosyal sermaye arasında köprü oluşturmak, farklı grupların bilgi, birikim, fikir ve yeniliklerin paylaşılmasına olanak tanır.

Kursal topluluklar tipik olarak daha güçlü bağlara sahipken daha zayıf köprü sermayesine sahiptir. Kentsel toplulukların ise güçlü köprüleme 
ancak daha zayıf bağlanmaya sahip oldukları öne sürülmüştür (Woolcock 2002). Bağlayıcı sosyal sermayenin olumsuz dışlama sonuçlarından farklı olarak köprü oluşturan sosyal sermayenin olumsuz etkileri çok azdır. Birisi yabancılarla her etkileşime girdiğinde köprü sosyal sermaye oluşturma firsatı vardır. Bu, etkinliklere, ilgi alanları veya spor gruplarına, derneklere ve sivil toplum kuruluşlarına katılırken olabilir.

Putnam, bağ kurmanın idare etmek için iyi olduğunu ancak farklı kaynaklara erişim sağladığından ilerlemek için köprü kurmanın çok daha önemli olduğunu düşünür. Köprü kurmaya bağlayıcı sosyal sermayeden daha fazla değer vermektedir. (Walseth, 2008). Putnam (2000), gevşek ağların veya bağların insanların ilerlemesine yardımcı olduğunu, ilerlemenin genellikle ağın daha iyi işler elde etmeyle ve kariyerde ilerlemeye yardımcı olabileceği sosyal hareketlilikle ilişkilendirir (Walseth, 2008). Nitekim yapılan mülakatlarda bir katılımcı şunları söylemiştir: “...Siyaseten rant için katılımlar artıyor. Alacağını alan gidiyor. 'Göründüm, CV doldurdum, yer edindim şimdi bu sayede $A B$ projesi yapıp master yapabileceğim' demeler başlıyor. Bu cihetle gelmeler hiç de az değil. Bu network içerisinde kendini var etme ihtiyacı olmalar başlıyor...” (Avukat, Erkek, 27).

Bir başka katılımcı şu şekilde ifade etmiştir:

"Gençliğin oldukça maddi kaygıları var. Bunun yam sıra sosyal medya sayesinde gençler ilgi ve temayüllerini keșfedip bu bağlamda yönelim gerçekleștirebiliyorlar. Eskiden Sivil Toplum Kuruluşlarn ihtiyaç sahiplerine maddi yardım yapma yahut yardımları ulaștırma mahiyetindeydi. Șimdi algılama başka șekillerde kendini gösteren maddi kaygilar üzerinde. Sosyal medya sayesinde psikososyal fayda ve bu anlamdaki etkinlikler artmış durumda. Gönüllülük işlerinin eğitim hayatına katkısı da gençler için bir başka maddi beklenti. Gençler gönüllülük işlerinden eğitimlerine katkı sağlamalarmı da bekliyor. CV'de bulunması gibi de düşünülebilir kişisel gelişim gibi de." (Öğrenci, Kadın, 23)
Katılımcılar, kariyer gelişiminde STK'ların önemli katkısı olduğunu belirtmektedirler. Gençler STK'ların, sosyalleşmeye yardımcı olma, farklı çevrelerden insanlarla bir arada olma ve ilişski geliştirme imkânı sunduğunu dile getirmektedirler.

Türkiye'nin Gençleri Araştırması (TGSP, 2018) raporunda, gençlerin kendilerini herhangi bir topluma ve gruba ait hissetme - hissetmeme durumları sorgulanmış ve genel olarak gençlerin toplum içerisinde kendilerini herhangi bir gruba ait hissetmediği görülmüştür. Yine aynı araştırma sonuçlarına göre günümüz gençlerinin en önemli sorunu ve endişesi işsizlik ve eğitimdir.

Christie Robertson'a (akt. Gök, 2015) göre gençlerin toplumdaki kapasitesini inşa etmek onların kendi gelişimlerini destekleyecek aktivitelerin daha geniş bir toplumla ilişkilendirildiği örgütsel faaliyetlere bağlıdır. Gençler ilerlemeleri için gönüllülük faaliyetlerini bir basamak olarak görmektedirler. Katılımcıların da ifade ettiği gibi gençler, akademik ve sosyal açıdan ilerlemek, aynı zamanda görünürlüklerini artırma, networklerini genişletme ihtiyacına binaen gönüllülük faaliyetlerinde bulunmaktadırlar. Yapılan bir araştırmada da insanların kendi özel ihtiyaçlarına hizmet eden gruplara katılmak istedikleri görülmektedir (akt. Gök, 2015). Gönüllüğün yükselişinin ele alındığı başka bir çalışmada; gönüllü olmanın önemli nedenleri arasında kendini geliştirme arzusu bulunmaktadır (akt. Gök, 2015). Bu bulgular STK'lara katılımın bireysel çıkarlarla ilişkili olduğunu göstermektedir.

Bu bağlamda sivil toplum kuruluşlarına katılım, bağlayıcı (bonding) tarzda kendi gibi benzer sosyal ilişkilerden, ilgi alanları veya hedefleri kendisinden farklı hareket eden yani köprü (Bridging) oluşturan sosyal ilişkilere doğru kaymıştır. Gençler, eğitim ve işsizlik gibi sorunlarla baş etme yöntemi olarak gönüllülük faaliyetlerine katılmaktadırlar. Fakat bu katılım (Bonding) yani 
bağlayıcı aynı tip insanlardan oluşan sivil toplum kuruluşlarının bir parçası olmak yerine kendini kariyer ve eğitim alanında bir adım öne taşıyacak olan STK etkinliklerine ve faaliyetlerine dahil olmaktadır. Bir amaç ve hedef çerçevesinde, kendine faydası olacağını farklı kurumların farklı faaliyetlere katılması ile "Parçalı katılım”da bulunduğunu söyleyebiliriz. Gençlerin hedeflerine ulaşabilmeleri için sivil kuruluşlarının araç görevi gördüğü de ifade edilebilir.

\section{KATILIMI ZORLAŞTIRAN FAKTÖRLER}

\subsection{Güven}

\subsubsection{Gençliğin Sosyal Katılımında Sivil Toplum Kuruluşlarına Güven}

Gençlerin sivil toplum kuruluşlarının marka (imaj, karakter, kimlik) değerlerine atfettikleri önem gün geçtikçe artmaktadır. Bilhassa 15 Temmuz 2016'da gerçekleşen başarısız darbe girişimi sonrasında yaşananlar sürecin büyük bir "güvenlik” endişesine yol açtığını göstermektedir. Bu tarihten itibaren gençler, gelecek kaygısıyla herhangi bir kuruma aidiyet oluşturmaksızın sivil toplum alanında faaliyet göstermek istemektedir. Gençlerin 15 Temmuz öncesi süreçte STK'larda faaliyet gösterirken söz konusu STK'nın bayrak, flama, rozet, önlük vs. gibi sembollerini kolay bir şekilde taşıdıkları ve bu faaliyetlerde görüntü vermekten çekinmedikleri görülmektedir. Ancak sonrasında yaşanan süreçte artık sembol ve görüntülerin bir çeşit “etiket” unsuruna dönüştüğü ve bu durumun yol açtığı kaygılar sebebiyle gençlerin STK’lara katılımında önemli ölçüde azalma görüldüğü gözlemlenmiştir.

Araştırmanın bu bölümünde gençlerin STK'lara katılımını etkileyen faktörleri, devlet kurumlarının STK'lara karşı şüpheci yaklaşımı, bu yaklaşımın bir sonucu olarak devletin kendine yakın kurumlarla iş birliği yapması ve bu iki durumun yarattığı sürecin STK'lara yönelik bir imaj kaygısına yol açması gibi üç temel sorun üzerinden incelenecektir. Sivil toplum kuruluşlarına yönelik güven ve güvensizlik faktörleri, çeşitli STK'larda görevli veya gönüllü olarak faaliyet gösteren 18-30 yaş aralığındaki gençlerle yapılan mülakatlar üzerinden incelenecektir.

\subsubsection{Devlet Kurumlarının STK Kaygıları}

Sivil Toplum Kuruluşları (STK'lar); devletin birey düzeyinde faaliyet göstermediği özel ve resmî kurumlar aracılığıyla erişim sağlanamayan alanlarda faaliyet gösteren kuruluşlardır. Bu anlamda devletin ve özel sektörün yapılandıramadığı ve bireylerin ortak kaygılarla bir araya gelerek oluşturdukları organik oluşumlardır. Tarihsel bağlamda Batı merkezli olan sivil toplum kavramı modernleşme ile hayatımıza girmiştir. Sosyoekonomik ve politik düzeyde devletin hemen karşısında beliren önemli bir aktör olarak doğmuştur. Türkiye'de ise yirminci yüzyılın başında kendini yeniden yapılandırmaya başlamıştır. Zira sivil toplum kuruluşlarının Osmanlı Devleti'nin güçlü devlet geleneği karşısında siyasal ve ekonomik bir irade olarak belirgin olmadığını ancak Cumhuriyet ile politik bir zemin kazanabildiğini söylemek mümkündür (Türkiye Üçüncü Sektör Vakfi, 2011).

Sivil toplum kuruluşlarının farklı formatlarda kendilerini ifade eden sosyokültürel ajandaları vardır. Böylelikle sivilleşen sahalarda faaliyet gösterebilmek daha kolay, yapıcı ve sürdürülebilir hâle gelir. Bu hâliyle sivil toplum kuruluşlarının misyon, vizyon ve hareket şemasını gösteren bu ajandaların şeffaf olması ve bireylerin bunlara kolayca erişebilmesi, kurumlara yönelik olumlu katılımı artıran önemli bir faktördür. Bu şeffaflık ve erişilebilirliğe rağmen devlet ve STKarasındayaşanan politikeksenli sorunlarzaman zaman katılımın 
engellenmesine zemin hazırlamıştır. Sivil Toplum Kuruluşları devletin karşısında söylem geliştirebileceği etkinlik alanını kaybettikçe bireylerin kurumlara aktif katılımını da etkilenmeye başlamıştır. Nitekim devletin ideolojik aygıtlarını kullanarak bireyler için sivil alan bırakmaması toplumun "yönlendirilmeye muhtaç", aksi hâlde "devletin varlığı için muhtemel bir tehdit" unsuru olarak görülmesine sebep olabilir (Gümüş, 2011). Böylesi bir algıyı yaratan devlet kurumları sivil toplum kuruluşlarına karşı güvensizlik yaratabilir. Bilhassa 15 Temmuz 2016'da yaşanan darbe girişimi ve sonrasında FETÖ kaynaklı sivil toplum kuruluşlarının geçirdiği hukuki süreç konunun "güvenlikleştirilmiş" bir alana çekilmesine zemin hazırlamıştır (Buzan, 2015).

Aralık 2020'de mevcut Dernekler Kanunu'nda yapılan bir yenilikle derneklerin kuruluş, üyelik ve denetim aşamalarındaki teamülde değişikliğe gidilmiştir. Aşağıda, kanunda yer alan ibare ile devletin aldığı önlemlerin arttığı görülmektedir:

"Gerekli görülen hâllerde, derneklerin tüzüklerinde gösterilen amaçlar doğrultusunda faaliyet gösterip göstermedikleri, defterlerini ve kayıtlarmı mevzuata uygun olarak tutup tutmadıkları İçişleri Bakam veya mülkî idare amiri tarafından kamu görevlilerine denetletilebilir. Bu denetimlerin, yapılacak risk değerlendirmelerine göre üç ylı geçmeyecek şekilde her yıl yapllması esastır. Bu denetimlerde kolluk kuvveti mensuplarn görevlendirilemez. İç̧̧̧leri Bakanlığ denetimler mesai saatleri içerisinde yapılır (Resmî Gazete, 2004).

Devletin terör ve terörle irtibatlı oluşumları önleme konusundaki adımlarının somut bir örneği olan kanunda, gerekli görülen hâllerde faaliyetten menetme ve görevden alıkoyma gibi hükümlerin de bulunuyor olması sivil toplum kuruluşlarının eleştirilerine sebep olmuştur. Bu hâliyle devletin STK kaygılarının kanun ve denetim çerçevesinde işlenmiş olması genç bireylerin de benzer endişeleri paylaşmalarına zemin hazırlamıştır.
Bu anlamda sivil topluma yönelik katılımdaki temel sorunlardan biri hâline gelen "güven" faktörü sivil toplum kuruluşlarında faaliyet göstermek isteyen gençlerin motivasyonunu olumsuz yönde etkilemeye başlamıştır. 15 Temmuz darbesinden hemen önce yapılan bir çalışmada gençlerin hâlihazırda STK'lara duyduğu güvenin devletin resmî kurumlarının çok gerisinde olduğunu ortaya koymuştur. Mayıs 2016'da yayımlanan bu raporda gençlere en güvendiği kurum sorulmuş ve gençler \%31,2 ile orduya (Silahlı Kuvvetler) güvenirken bu oran, verilen cevapların en düşük yüzdesini teşkil eden STK'larda \%12,7 olarak saptanmıştır (Vatandaş vd., 2016). Görüldüğü üzere gençlerin Türkiye'de sivil toplum kuruluşlarına yeterli düzeyde güven duymaması 15 Temmuz sürecinin yol açtığı sorunları daha hissedilir kılmıştır.

Gençlerin sosyal katılımın bir parçası olmaya yönelik iştiyakı sivil toplum ve devlet kurumları arasındaki politik ilişkilere bağlı olarak değişim göstermektedir. Bilhassa 15 Temmuz Darbe Girişimi'nden sonra, devlet kurumlarının STK'lara olumsuz bir bakış geliştirmesi bahsi geçen "politik tabanlı" değişimin somut bir örneğini teşkil etmektedir. Tabanda yaşanan sosyopolitik aksiyon devlet eliyle kontrol altına alınmak istenmiş ve bu durum ilerleyen süreçte sivil toplum kuruluşlarına katılımda güven sorununu ortaya çıkarmıştır. Katılımcılardan biri devletin STK'lara yönelik kaygılarını sahadan şu şekilde aktarmaktadır:

“STK geleneğimizden geldiği için çok fazla vardır. Her dönemde vardı. Devlet ne vakit (bu) alanlarn daralttı ve tek tipleștirdi, sivil toplum eridi. Sivil topluma alan daraldıkça tartışma ortamı da biter. Yeni "genç" tartışmazsa ve sorgulamazsa STK'lar tarihe karışır. Kafada biter. Kamusal demokratik alan kaybedilirse gençlik de paralel olarak kaybedilir." (STK Çalışamı, Erkek, 27) 
Görüldüğü üzere devlet eliyle sivil topluma yönelik uygulanan kısıtlamalar sivil toplumun mahiyetini ve işlevsel sürekliliğini değiştirmektedir. Olumsuz bir algının doğrudan değilse bile dolaylı yollardan etkilediği STK'ların varlığı üzerinden bir problematik yaratmak, ilerleyen süreçte sivil toplumun hareket alanını azaltma tehlikesine açıktır. Bu senaryonun gerçekleşmemesi için gençlerin sivil topluma katılımına yönelik endişelerinin devlet kurumlarınca giderilmesi ve özgür bir sivil toplum tesis edilmesi gerekmektedir.

Gençlerin STK'lara güveni ile kastedilen durum, en temel mânâda "güvenlik" meselesi hâline getirilmemiş sivil bir alan talebinden müteşekkildir. Devletin sosyal sorumluluk projeleri ve sivil katılım faaliyetlerini devlete daha yakın duruş sergileyen kuruluşlarla yürütmeye başladığını söylemek mümkündür. Devlet kurumları erişilebilir kurumsal ajandalar, şeffaflık, STK’ların imajı ve taban kitlenin cemiyet - cemaat intisabını göz önünde bulundurarak sivil toplumun üzerinde kontrol mekanizmalarını artıran teşebbüslerde bulunmaktadır. 15 Temmuz Darbe Girişimi sonrasında devletin, STK'ların kurucu kadroları, kurucu ideolojisi ve dinî - mezhepsel intisap faktörünü göz önüne alan bir yaklaşım geliştirmesiyle gençlerin STK'lara yönelik olumsuz bir algı geliştirmesi kaçınılmaz olmuştur. Böylelikle sivil toplumdaki sivil akademik, sosyal yardımlaşma ve gençlik yapılanması gibi oluşumlara katılım azalmaya başlamıştır. Bu durum gençlerin STK'lara olan güveninde problematik bir sürece girildiğine işaret etmektedir.

15 Temmuz Darbe Girişimi öncesinde STK'ların kurumsal bir kimlikle yürüttüğü çeşitli bilimsel, sportif ve kültürel faaliyetler devletin kontrol ve teşviki altında yapılmasına rağmen darbe kalkışmasının akabinde yaşanan sorunlar gençlerin süreci doğru okuyamamasina sebep olmuştur. Genç, lise yıllarından beri devlet eliyle teşvik edildiği çeşitli platformlarda kendini sosyalleştirme imkânı bulmuş, çeşitli sosyal sorumluluk projesinde görev almış ve aktif bir katılımcı olarak sürecin öznesi olmuştur. Ancak üniversite yıllarında yaşanan politik tabancı sorunlar devlet ve sivil toplum kuruluşları arasındaki mesafeyi artırmıştır. Bu konuda çeşitli STK’larda aktif, yönetici/organizatör konumunda bulunan mülakat katılımcılarından biri, açıklamalarıyla gençlerin STK'lara aktif katılımının 15 Temmuz Darbe Girişimi sonrasındaki sivil toplum çalışmalarını olumsuz etkilediğini aktarmıştır:

"FETÖ etkisi burada (gençlerin sivil topluma aktif katılımında) çok önemli. 7. sınıf öğrencilerini (dernek ve vakıflardaki) çalışmalara gönderen aileler FETÖ olaylarından dolayı tedirginler mesela. Bu anlamda insanlar artık 'bağllı̆̆ı olan STK'lardan uzak durmahyım' diye düsünüyorlar. (Bağhllık gibi olan) Yakınlık bile uzak durmaya yetiyor. Kamu tüzel kişiliklerine, işte Kızılay gibi, daha çok yönelim var bu yüzden." (Öğrenci, Erkek, 22)

Kendi sosyal çevresini kurmak isteyen genç bireyler, kendileri ile aynı duygu ve düşünceleri paylaşan, ortak bir amaca hizmet etmek için kurulan kurum ve kuruluşların çatısı altında belirli faaliyetler yürütmektedir. Bu faaliyetlerde görev alan biri son yıllarda yaşanan katılımcı sorunlarına şu sözleriyle dikkat çekmektedir:

"Bir kurumda görev almadan önce artık soruyoruz, 'Hükümet karşıtı bir söylem var mı?' yahut 'Devletin herhangi bir organma vs. kurumuna zararl olacak söz ve eylemleri var m??' diye. Devletimizi seviyoruz ve tabii ki önce düzen ve işleyiş önemli diyoruz. Ancak bu durum bazı noktalarda can sıkıcı olmaya başladı çünkü siyasal alam topyekûn sivil topluma enjekte ettik. Bundan dolayn gençler burayı da siyasi bir parti gibi görüp gelmiyor. Gelen de siyasi görüşünden dolayı yakınlık duyduğu için geliyor. Gönüllü olarak sahada yardım faaliyetleri yapacağız mesela, bazı gençler vakfin kurumsal sembolleri var diye fotoğraf çekilmek istemiyor. Bu vakıfla görünmeyeyim, gelecekte ne olacağı belli olmaz mantığı hâkim. Bir de devlet temkinli kurumlara karşı. Vatandaşa da yansıyor bu. Çocuğunu göndermek istemiyor." (Gazeteci, Kadın, 26)

Görüldüğü üzere gençliğin sosyal katılımında STK’ların başat aktör olarak ön plana çıkmasının resmî devlet kurumlarınca yürütülen 
güven ve iş birliğine dayalı olması gerekmektedir. Bu hususta STK'lar devletin "güvenlikleştirilmiş" alanlarından uzaklaştırılmalıdır. Sahadaki gözlemlere binaen, genç katılımcıların endişelerinin devletin beka ve istikrarına yönelik endişelerin de ötesine geçerek daha uzun vadede bir gelecek kaygısına dönüşmesi kaçınılmaz olacaktır. Ailelerin bu süreçte devlet ile benzer çekincelerle hareket etmesi gençler üzerinde etkili olmaktadır.

\subsubsection{STK'ların Kurumsal İmajı ve Gençlerin Sosyal}

\section{Katılımı}

Sivil toplum kuruluşlarının, bilhassa 15 Temmuz sonrasındaki süreçte, yaşadığı temel sorunlardan birisi de kurumsal imaj ve aidiyet sorunudur. Kurumların bağlı oldukları ideolojik köken, dinî motivasyonlu cemaat yapıları, finanse edildikleri iş grupları gibi karşılıklı bağlılığı ifade eden ilişkiler gençlerin STK'lara katılımını zorlaştırmaktadır. Sivil toplum kuruluşlarının örgütlenme modelleri, kendilerini oluşturan organların özgürlüğü ve cemiyet prensipleri oluşturmadaki demokratik ve hukuki haklarını kullanma biçimleri sivil topluma ait ögeler içermesi açısından önemlidir. Türkçede en genel biçimde "cemiyet” olarak tanımlanan ve bir grup insanın ortak kaygılarıyla bir araya gelerek oluşturdukları vakıf ve dernek gibi kurumlar, belirli bir amaca ulaşmak ve bu hususta kişisel bir kar gütmemek gibi ilkelerle bir yapı inşa etmektedir. Bu inşa sürecine yapılacak müdahaleler, kurumların demokratik unsurlarına zarar verme endişesini de beraberinde getirmektedir. Dolayısıyla bu gibi kurumların özgürlüğü, genç bireylerin buradaki aktif katılımına doğrudan tesir etmesi bakımından önemlidir.

Kurumların bu anlamda özgür olması onların topyekûn zararsız olduğu anlamına gelmemektedir. Gerektiği ölçüde düzen içerisinde olmaları devlet organlarının işleyişi ve istikrarı için önemlidir. Ancak düzen içerisinde dahi olsa farazi tehlikelerden endişe duyulduğunda kısıtlayıcı, hedef gösterici ve hatta menedici bir tavırla STK'ların saha dışı bırakılması söz konusu olabilmektedir. Böyle zamanlarda toplumun çeşitli kesimlerinde sivil toplum karşıtı bir algının oluşması muhtemeldir.Politik dengeleme veyapıcı bir üslup çerçevesinde, temel ilkesi özgürlük olan bir yaklaşımla STK'ların faaliyet özgürlüğünün bulunması, gençlerin buralarda sosyalleşmesi ve kişisel gelişimlerini tamamlaması sivil toplumun var olma amacı açısından önemlidir. Aksi takdirde bu olumsuz algı ile gençler STK'ların kurumsal kimliklerine bakarak buralarda aktif katılımcı olmaya mesafeli bir tavır sergileyecektir. Konuyla alakalı katılımcılardan biri sözleriyle devlet ve sivil toplum örgütleri arasındaki ilişkinin gençler üzerindeki olumsuz etkisini aktarmaktadır:

"STK'ların kimlikleri temsil ediyor oluşu önemli. Şu an iyi olan kurumun yarın hangi etiketle anılacağını kimse bilmiyor neticede. Çoğunlukla bir kimliği temsil etmeyen ve çeşitliliğe yer veren STK'lara katılmayı tercih ediyorum. Kime hitap ediyor meselesi biraz daha problematik. Bir yana daha çok eğilmeden, her kesimden katılımcı barındıran kurumları tercih ediyorum. Bir STK'nın hiçbir ideolojiye eklemlenmemesi esas olan. Aym masada vegan, eş cinsel, muhafazakâr oturabiliyor mu buna bakıyorum." (Öğrenci, Kadın, 22)

Katılımcıya göre gençler, bugün devletin sakıncalı görmediği sivil toplum yapılanmalarına karşı "geleceğe yönelik" kaygılar gütmekle beraber mevcut STK'ların imaj ve kimliklerine karş1 bir belirsizlik hissi içerisindedir. Toplumun geniş ölçekte birçok kesimine hitap edebilen, tek tipleştirme hedefleri olmayan ve herkesin demokratik bir biçimde söz hakkı alabildiği sivil toplum yapıları tercih edilmektedir.

Bir başka belirsizlik örneği ise cemaat ve tarikat destekli sivil toplum kuruluşlarının içinde bulunduğu durumdur. Bu kuruluşlar her ne kadar bugün anayasal haklarından yararlanıp hukuki bir zemine dayanarak 
faaliyet gösterseler de gelecekte ne olacağına dair endişeler gençlerin gündemini meşgul etmektedir. Gençlerin bu konuda "bugün iktidarın yanında olan kurumlar yarın olmayabilir" kaygısına sahip olduğunu söylemek mümkündür. Bu konuda STK'larda aktif olarak yönetici kadrolarda görev alan bir başka katıllımcı sözleriyle mevcut belirsizliğin aslında uzun vadede bir imaj sorunu yarattığından söz etmektedir:

"Biz mesela eskiden, yani 2016 yılı öncesinde fakülteden arkadaşlarla bir STK'da gönüllü olacaksak çok düşünmezdik, yani bunlar şucu mu bucu mu diye. Devlet adamlan diyoruz ya, hani milletvekilleri, bürokratlar vs. falan bu kurumlarda diye düşünmüyorduk pek. Hatta Başbakan ile programlarn bile var vakıflarm diye rahat rahat rol alıyorduk organizasyonlarda. Ama 15 Temmuz'dan sonra arkadaşlar hiçbir yere gidip de gönüllü olmamaya başladr. Bu süreçte ailelerimiz de temkinli tabii. Biz de bir bakıyoruz Başbakan bile bizimle organizasyon yapmış bu kurumda ama kurum şimdi terörist diye kapatılmış. Tuhaf bir belirsizlik var. Devlet sakıncalı gördü bugün ama dün görmemiști mesela." (Öğrenci, Kadın, 25)

Katılımcının bu noktada ebeveynlerin de bu belirsizlik sürecinin bir parçası olduğunu vurgulaması gençlerin aile ve çevre motivasyonundan kaynaklı olarak kurumlara karşı mesafeli tavrını göstermesi açısından önemlidir. Bununla beraber aynı katılımcı gönüllü olarak görev aldığı kurumda yürüttükleri çalışmalardan şu şekilde bahsetmektedir:

"Bașta endișe ediyorduk ancak șimdi finansörlere ve organizasyonun beraber çalıștiğı isimlere bakınca bağımsız olduğunu görüyoruz. Mesela filanca siyasi partinin yahut vakfın uydusu bir organizasyon değil. Bu artı güven veriyor. Ortada bir kurum olacak yani. Öteki türlü sadece kendi mensuplarımı çocukları katılımo oluyor. Dışarıdan bir genç, kurumun imajından dolayı korkuyor, gelmiyor."

Bu ifadeler, sorunun temelde gençlerin katılımcı olmasının önündeki engellerden biri olan "imaj” sorunu olduğunu ortaya koymaktadır. Böylelikle üniversite çağındaki gençlerin okulu bittikten sonra iş hayatında kendisine sorun yaratmayacak bir sosyal katılım yahut kısa süreli bir "gönüllülülk" faaliyeti aradığı tespit edilmiştir.

\subsubsection{Devlet Destekli Sivil Toplum Kuruluşları}

Devlet ve/veya siyasal iktidar bazı durumlarda kamu hizmetlerinin daha geniş ölçekte ve daha erişilebilir olması açısından bazı STK'lara önemli roller vermektedir. Demokrasi açısından sivil toplum ve devlet arasındaki olumlu ilişki halkın aktif katılımcı olmasını ve kamu hizmetlerinden adil ölçüde yararlanılmasını amaçlamaktadır. Bu durum bazı önemli tehlikelere açıktır. Devletin bu hizmetlerin niteliği ve sürekliliği hakkındaki nihai karar yetkisini söz konusu kurumlara devretmeden yapması gerekmektedir. Bilhassa siyasal iktidarların kendi nüfuz alanındaki özel kuruluşlar göz önüne alındığında söz konusu devir işlemi eleştirileri beraberinde getirmektedir. Zira özel kuruluşların sorumluluğuna bırakılan hizmet, organizasyon ve projeler sivil toplumun siyasallaşmasına sebep olmaktadır. Bu ise millî güvenlik ve çıkarların korunmasında endişeye kapılan hükümetlerin sert tedbirler almasına yol açabilir.

Sivil toplumun önümüzdeki on yılının gündeminde "güvenlik" kavramının önemli bir yer tutacağını söylemek mümkündür. FETÖ'nün başlangıçta bir paralel devlet yapılanması olarak ortaya çıkmasında sivil alanda köklü STK'lar inşa etmesinin rolü büyüktür. Bu terör örgütü, bilhassa gençlere yönelik kurduğu STK'lar aracılığıyla örgüte eleman devşirmeyi hedeflemiştir. Bu anlamda öğrencilere konaklama ve burs gibi temel imkânlar sunabilmek adına tesis ettikleri STK'ları birer propaganda aracına dönüştürmüşlerdir. 2016 yılındaki başarısız darbe girişimi ile FETÖ’nün zaten deşifre olmuş bu sistemi kademeli olarak çökmüştür. Ancak geride diğer tüm STK'ları önemli ölçüde zan altında bırakan kırık bir STK algısı bırakmıştır. Bu sebeple Türkiye'deki STK'lar için 2016 yılının bir dönüm noktası olduğunu söylemek yanlış olmayacaktır. Bu konuda bir katılımcı şu sözleri sarf etmektedir: 
"Biz lisansta öğrenciyken (2016 öncesi) birkaç arkadașımla bir kurumda gönüllü olarak kampanya yürütüyorduk. Yardım kurumuydu bu. Ancak darbeden sonra kuruma bakanlıktan kayyum geldi. Birkaç yönetici soruşturmaya falan alındı. Bizim kurumla resmen bir ilişiğimiz yoktu. Sadece ücretsiz olarak yardımları sahiplerine ulaștırmak için oraya gidip gelirdik. Ancak 2016'dan sonra darbe sebebiyle hiçbir kuruma yardım paketi taşımak için bile olsa gitmedik. Ben ve üç arkadaşım tüm STK faaliyetlerini bıraktık. Șimdi belediyeler ile yardım kampanyası yapıyoruz... İște mesela büyükşehirle falan... Ama tabii seçimden sonra yönetim değişince kadrolar değişiyor ve sizi aralarnna almıyorlar artık. Böyle de bir şey oldu..." (Öğrenci, Erkek, 25)

Devletin 2016 yılı itibariyle beka ve demokrasinin sürekliliği için aldığı tedbirler sivil toplumda özgürlük ve katılım konularında bir daralma yaşanmasına neden olmuştur. Bu daralma ile devletin, yardım ve kampanya süreçlerini yakından takip edebildiği, faaliyetlerinin kontrol edilmesi kolay ve iktidara görece daha yakın tavır sergileyen kurumları desteklediği görülmektedir. Böylelikle bazı STK'ların siyasetten uzak; günlük yaşamdaki toplumsal sorunların kaynağına ve bunların çözümlerine eğilen yapısından uzaklaşıldığı tespit edilmiştir. Halk ve devlet arasındaki irtibatın güçlenmesi için teşvik edilen bu "Devlet Destekli Sivil Toplum Kuruluşları”, sivil toplumun mantığı, mahiyeti ve amacına yönelik tartışmaları da beraberinde getirmiştir.

Demokrasi için olmazsa olmaz olarak görülen "aktif katılımcılık" ilkesi, STK'lara olan katılımın keyfiyetiyle de yakından bağlantılıdır. Dolayısıyla devletin birinci kanaldan teşvik ettiği kurumların dışında kalan STK'lara aktif katılımda azalma yaşanması, söz konusu aktif katılım ilkesini tartışılır hâle getirmektedir. Bu hususta mülakat katılımcılarından biri söz konusu tartışmayı şu şekilde aktarmaktadır:

"Sivil alan çok daraldr. Tekelleşme, sosyal medyanın kontrolü gibi siyasal müdahaleler ile gençlerin kısıtlandığın görüyoruz. Şu anda gündemler hep aym. Tek gündemcilik var. Tüm STK'lar aymılaștı. Sivilleșme yok. Hepsi siyasi bir çatı altında. Siyasal düzlemde hepsi aynı olunca gençler kendini ifade edecek bir yer olmadığ 1 için katılmıyorlar diyebiliriz. STK'ların bir çekiciliği kalmadı. Her gidilen yerde aym insanlar ayn konuşmalar oluyor. Üretim de kısıtlanınca gençler için (katılımın) bir numarası kalmıyor." (STK Çalışanı, Erkek, 27)

Söz konusu STK'ların devlete görece daha yakın olanlarla benzer ajandalara sahip olmaları, devlet desteği ve teşvikiyle bir yol izlemeleri bazı sorunları beraberinde getirmektedir. Katılımcının ifadesiyle sahada "tekelleşme" ve "aynılaşma" olarak akseden bu durum, STK’ların gençlerin anlam dünyasındaki yerine de zarar verebilmektedir. Bu nevi tehlikeler ile STK'ların bünyesindeki faaliyetlere katılamayan ve kendilerini ifade etme imkânı bulamayan gençler, doğru vatandaşlık bilincinin yerleşmesinde de sorun yaşamaktadır. Siyasi bir çatı altında yürütülen organizasyonlar, seçim kaygısıyla politika belirleyen siyasal partiler açısından da sorunludur. Zira bugün iktidarda olan A partisine yakın bir STK'nın seçimle başa gelen B partisinden sonra “zararlı” bir oluşum olmayacağının garantisi yoktur. Bu hususta katılımcılardan birinin sahadan aktardıkları gençlerin anlam dünyasını görebilmek adına önemlidir:

"Sorun devletin, aslında hükümetlerin belirleyici olması. Bu demokratik ülkelerde bir kademede normaldir diyebiliriz. Ancak STK'lar Türkiye için sosyal devlet olmanın da kıstası bir yerde. Biz arkadaşlarla bir kurumdan dil dersleri alıyorduk. Bize kitap satın almamız için yardım kuponlar veriyorlardı. Sonra bir sabah bir uyandık bu STK filanca siyasi partiye yakın diye kaldığımız yurdun müdürü tarafından fişlenmişiz. Müdürün odasına çağırılıp uyarıldık. Muhatap olduğumuz bu sorunlar yüzünden bir daha o STK'daki bedava dil derslerine gidemedik. Çok üzücü çünkü herkes kendi mahallesinde oynasın mantığ var. Ancak biz 1990'l y yllarda değiliz. Gençlerin istekleri çok farklı. Doğduğumuz dünya çok kutuplu olsa da büyüklerimiz ve STK'larımız hâlâ tek kutuplu. Biz Soğuk Savaş çocuklarn da değiliz. Daha özgür, mobilizasyonu esnek bir sivil toplum istiyoruz." (Öğrenci, Kadın, 25) 
Gençlerin akademik anlamda kendilerini geliştirmeleri için kurulan vakıf ve derneklerin devlet destekli projelerde olması yahut devlet kurumlarınca finanse edilmesi gençlerin bu kurumlar dışında kalan kurumlarda aktif olmasına imkân tanımamaktadır. Bir vakıfta akademik gelişime yönelik dersler aldığını söyleyen bir başka katılımcı ilerleyen süreçte vakfin yönetim kurulunun devlet tarafindan görevden uzaklaştırılmasıyla yaşadığı "uzaklaşma" sürecini şu sözlerle aktarmıştır:

"Lisans eğitimimiz dışında bu kurumda ylllarca akademik dersler aldık. Seçkin hocalarla çeşitli faaliyetler yürüttük. Ancak siyasilerin sorunları bir çeşit 'güvenlik' sorunu hâline geldi. Sorunlar baş gösterince ben dâhil birçok arkadaş dersleri bıraktık. Artık sembollere göre hareket ediyoruz. Filanca insan iktidar karşıtı yahut iktidara yakın ise onun olduğu kurumda faaliyet yapmiyoruz. İki tarafa da mesafe koyuyoruz. Yarn bir gün CV'mizde yazan bir vakıf tecrübesi işimize engel olmasın diye. Türkiye çok kaotik çünkü. Gelecekte ne olacağın bilmiyorsunuz. Bu yüzden herkes devlet kurumlarına saldırıyor diyebilirim. Özellikle Gençlik ve Spor Bakanlığı'nın iş birliği yaptığ kurumlara yöneliyoruz. Ancak bunda da siyasal yakınlık duyanlar geliyor mesela muhalif partilerden arkadaşlar katılmıyorlar.” (Öğrenci, Kadın, 25)

\subsection{Aile Beklentileri ve Gençlerin Sosyal Katılımı} Üzerine

Gençlerin toplumsal faaliyetlere katılımına ilişkin hususlarda ayrıca üzerinde durulması gereken bir nokta ise ebeveynlerin bu konuda aldıkları pozisyondur. Ebeveynlerin çocuklarının katılımı hakkında ne düşündüğünü anlamak için bu durumu iki açıdan sorulan sorularla ortaya çıkarmak mümkündür:

1) Ailelerin çocuklarm sosyal katılıma teşvik eden motivasyon ögeleri nelerdir?

2) Ailelerin çocuklarımın sosyal katılımına dair çekincelerinin sebepleri nelerdir?

$\mathrm{Bu}$ iki soru ailelerin çocuklarına dair tutumlarını belirleyeceğinden etkisini genel perspektifte gençlerin katılımı üzerinde gösterecektir. Aileler çocuklarını sosyal katılım faaliyetlerine yönlendirirken daha çok fayda odaklı düşündükleri belirtilebilir. "Çocuğum bu katılıma dâhil olarak ne elde eder?” sorusuna doyurucu cevap verebilen ebeveynlerin çocuklarını sosyal katılım konusunda teşvik ettiğini belirtebiliriz. Örneğin katılımcılardan biri şu ifadeleri kullanmıştır:

"Ailelerin katıldığımı işlerden para veya burs beklentisi var. Eğer burs almıyorsan aileler bunu eleștiriyor. Burs için gönüllülük çalışmalarının bu kadar çok olmasının bir sebebi de bu durumun ailelerin de isteklerine hitap etmesi." (Öğrenci, Erkek, 22)

Yine başka bir katılımcı "maddi karşılığı olmadan yapılan gönüllü işler hamallık olarak görülüyor. Aileler gönüllülük faaliyetlerine daha çok maddi kaygı ile bakıyorlar." demiştir (Öğrenci, Kadın, 23). Öyleyse ailelerin çocuklarının sosyal faaliyetlere katılımlarında "maddi bir neticeye" odaklandıklarını belirtebiliriz. Aileler çocuklarının aktif olarak yer aldığı faaliyetlerde çocuklarının faydalarını doğrudan ve açıkça görmek istiyorlar. Bununla birlikte ailelerin gençlerin sosyal katılımına ilişkin bazı çekinceleri olduğunu da belirtmekte fayda var. İlk dikkat çeken çekincelerden biri şöyledir:

"Özellikle de FETÖ olaylarmdan sonra ailelerde büyük bir çekince oluştu. 'Herhangi bir bağhllı̆̆ olan sivil toplum faaliyetinden uzak durmalyyım.' diyebileceğimiz bir durum oluştu. Bu yüzden Kızlay vb. kamu destekli kurumlara daha çok yönelim var." (Öğrenci, Erkek, 22)

Ülkenin siyasi ve toplumsal tecrübeleri aileler için bazı kaygılara sebep olmakta bu da çocuklarını bu tür faaliyetlerden alıkoymaları ile neticelenebilmektedir. Aile ve ailenin yönlendirmesi veya sakındırması gençlerin sosyal katılım sürecine dâhil olmalarında doğrudan bir etkiye sahiptir. Ailelerin faaliyetlerden çocuklarının elde edecekleri faydayı direkt görmek istemeleri göz önüne alındığında gençleri bünyesine katmak isteyen kurumların bu faaliyetlerle gençlerin elde 
edeceği net faydayı dolaysız olarak sunması gerekir. Bununla birlikte gençlerin aktif katılımını talep eden bu kurumlar herhangi bir oluşum veya hareketin renklerinden kendilerini âri tuttukları ölçüde daha az çekince ile karşı karşıya kalacaklardır.

\subsection{Arkadaş Baskısının Gençlerin Sosyal Katılımına Etkisi (Peer Pressure)}

Gençlerin sosyal katılım süreçlerine etki eden bir diğer önemli faktör de arkadaş çevresi ve onların oluşturduğu baskılardır. Gençlik döneminin sosyal çevreden gelen eleştiriler karşısında kırılgan bir dönem olduğu ve kişilerin kendi hayatlarını şekillendirirken bu eleştirilere merkezî bir rol verdiği göz önüne alındığında bu durum önem arz eder. Bu bağlamda katılımcıların belirttiği bazı hususların altını çizmekte fayda vardır.

"Ücret veya kazanç olmadiğ zaman gönüllü iş yapmak arkadaş çevresi tarafindan desteklenmiyor. Arkadaş ortamında kabul gören bir davranıs olmadiğı için de gerekli motivasyon kalmıyor. Bu motivasyonun artırılması okullarda özellikle liselerde yapllacak temel gönüllülük eğitimlerinin yapılması ile sağlanabilir." (Öğrenci, Kız, 23)

$\mathrm{Bu}$ durum gençlerin katıldıkları sosyal faaliyetlerinin maddi bir çıktısının olup olmamasının çevrenin bu faaliyetlere karşı tutumunda belirleyici olduğunu gösterir. Maddi bir şey elde etmeksizin yapılan faaliyetler takdir edilmediği için bu süreçte aktif rol almakta olan katılımcının da motivasyonu olumsuz etkilenmektedir. Öyleyse çevrenin açıkça farkında olacağı ve onaylayacağı bir kazancın gençlerin katılım süreçleri için sunulması çevrenin desteği bakımından önemlidir. Zira diğer bir katılımcı çevrenin motivasyona dâhil olup koordinenin kurulabildiği durumlarda katılımın güçlendiğini şu sözlerle vurgulamıştır: "Gönüllülük işlerinde arkadaş ve çevre motivasyonu çok önemli. Resmi olmayan fakat sürekliliği olan bir ekiple iş yapabilirliğimiz oluşuyor. Liderlik, teşvik gibi durumlar varsa çevreniz size ayak uyduruyor." (Öğrenci, Erkek, 23)
Sosyal faaliyetlere katılan kişilerin bir motivasyonun da çevrelerine bu faaliyet sonucunda elde ettikleri kazancı açık bir şekilde sunabilmeleri olduğu görülmektedir. Öyleyse hem bu gençlerin katılımını artırmak hem de çevreleri için bu işi çekici hâle getirmek adına gençlerin bu faaliyetler neticesinde elde ettikleri kazancın net ve açık olması gerekmektedir. Aksi hâlde çevreden alacakları olumsuz tepkiler doğrultusunda gençlerin katılım için gerekli motivasyonu kaybetmeleri riski ile karşılaşılabilir.

\section{SONUÇ VE ÖNERILER}

Sosyal medya geleneksel sosyalleşme anlayış ve pratiklerimizden keskin ayrılıklar gösteren, zaman ve mekân algısı karmaşık, çok zaman hızlı ve anlık olma özelliklerini de içinde bulunduran yeni bir platform olarak birçoğumuzun hayatında vazgeçilmez yerini almış durumdadır. Sosyal medyanın oluşturduğu "alternatif dünya” kullanıcılarına aktif ve doğrudan, karşılıklı etkileşime açık bir katılım formunu sunmuş ve kişiler, bu dünyanın bireyleri olarak kendilerine ait bir ifadelendirme çerçevesini de bu bağlamda oluşturmaya başlamıştır. Sosyal medyanın oluşturduğu bu yeni katılım formlarının içerikleri iyi çözümlenmeli ve bu vasıtaların sağlayacağı verimler dikkate alınmalıdır.

Dijital katılım formu ile sosyalleşen bireyler, bu platformlarda birtakım sıkıntılarla karşılaşmaktadır. Bunlar ailevi, toplumsal ve bireysel düzlemlerde birtakım problemler teşkil etmektedir. $\mathrm{Bu}$ problemler için toplumu oluşturan aktörlerin ve sivil kurumların çeşitli önlemler alması gerekmektedir. Birinci problem olarak kimlik oluşumunun olumsuz etkilenmesi zikredilebilir. Nitekim bireyler özellikle gençlik dönemlerinde kendilerinden memnun olmadıkları birtakım özelliklere sahip olduklarını düşünmektedir. Bunları kabul etme veya geliştirme yerine dijital dünyada istedikleri özelliklerde sahte kimlik inşa etmektedirler. Bu durum bireyin kendisiyle barışık 
olması, öz farkındalık, bireyin gelişimi ve olgunlaşmasını olumsuz etkilemektedir. İkinci problem sıkça karşılaşılan kandırılma ve suistimal edilme vakalarıdır. Dijital platformlarda anonim veya sahte kimlik kullanan kişiler birtakım amaçlar doğrultusunda insanları kandırmakta ve iyi niyetleri suistimal etmektedir. Aynı zamanda toplum tarafindan mahrem olarak kabul edilen unsurların bireyin izni olmadan ifşa edilmesi gibi durumlarla karşıllaşılmaktadır. Bu durumlar bireyin toplum karşısında itibarını zedelerken ruhsal bozukluklara da yol açabilir.

Dijital platformlarda problem teşkil eden bir diğer unsur yasal sorunlar ve özgürlük hakkı ihlalidir. Dijital dünyanın bireyler üzerinde gerçeklik karşılığg olmadığından, birey her türlü hak ve özgürlük ihlali gibi suçlar işleyebileceği düşüncesine kapılmaktadır. Bu durumlar günümüzde linç kültürü (itibarsızlaştırma) olarak bilinmektedir. Bu tip durumların dijital platformlarda meşru görülmesi kişinin gerçek hayatında kuralları tanımamasına ve suç eğilimi göstermesine yol açabilir.

Popüler ve beğenilir olma isteğinin (özentilik) yoğun bir şekilde yaşanması da dördüncü problem olarak zikredilebilir. Popüler kültürle birlikte bireyler insanlar tarafindan takip edilme ve beğenilme isteği duymaktadır. Bu isteğin yerine gelmesi için bireyler öz kimlikleri yerine dijital bir kimlik inşa etmektedir. İnşa edilen bu kimlik ise bireyin öz kimlik inşasını olumsuz etkilemektedir. Aynı zamanda bireyler popüler olma ve beğenilir olma uğruna aile ve toplumun öngörmediği davranışları yapma eğilimi göstermektedir. Kişinin popülerliğe sahip olması ise kaybetme korkusu oluşturmaktadır. Popülerlik trendinin yitirilmesi ile kendini dijital toplumdan dışlanmış hisseden kişi ruhsal çöküntü ve öz kimlik kaybı gibi sorunlarla karşılaşabilir.

Mahremiyet duygusunun zarar görmesi ve yalnızlaşma sorunları dijital platformlarda sosyal katılım çerçevesinde yaşanan diğer problemlerdir. Her bireyin kendine ait sınırları vardır. Bu sınırlar bireyin mahrem gördüğü kısımlardır. Dijital dünyada ise bu sınırlar önemsenmediğinden bireyler mahrem olan yazılar, konuşmalar ve görseller gibi içeriklere maruz kalmaktadır. Bu olumsuzluklar zamanla bireyde mahrem algısını değiştirip normal görmesine yol açmaktadır. Sosyal faaliyetler içinde bulunmayan sadece dijital sosyal katılımı tercih eden bireyler otokontrolü sağlayamadığı taktirde toplumdan uzaklaşma ve yalnızlaşma sürecine girmektedir. Bu süreç bireyin eğitim, iş ve aile yaşantısındaki ilişkileri olumsuz etkilemektedir.

Dijital katılım biçiminin doğurduğu problemler ve değiştirdiği sosyalleşme biçimlerimiz bir yana, gençlerin STK'lara katılımlarında da çeşitli nevzuhur dönüşümler mevcuttur. Gençlerle yaptığımız mülakatlardan elde ettiğimiz bilgiler gençlerin katılımlarının, bağlayıcı sosyal sermayeden köprü oluşturan sosyal sermayeye doğru kaydığını göstermektedir. Gençler STK’lara zayıf bağlarla bağlıdır. Farklı grupların, bilgi, birikim, fikir ve yeniliklerin paylaşılmasına olanak sağlayan, kendi gelişimlerine, kariyerlerine katkı sağlayacak köprü kuran sosyal sermaye ilişkilerine katılmaktadırlar. Rekabetin arttığı günümüzde gençler, deyim yerindeyse en güzel çiçekten bal toplayan arılara benzetilebilir. Kendilerini en iyi şekilde geliştirmek ve güzel bir gelecek elde etmek için gençler, gelişimlerine destek olacak birçok farklı STK'nın çalışmasına katılmaktadır. Bu bağlamda STK'ların, değişen bu katılım motivasyonunu göz önünde bulundurması, gençleri iyi tanımaları ve kariyer gelişimlerine katkı sağlayacak unsurları öne çıkaracak ihtiyaç temelli faaliyetleri planlamaları gençlere ulaşma ve iletişim kurmaları noktasında önemlidir.

Farklı motivasyonlara dayanan gönüllülü̈k tecrübesi de zamanla değişime uğramakta ve yeni formlara girmektedir. Yeni katılım formu ile karşılaştırıldığında kuruma daha bağlı, sürekli ve topluluk hâlinde gerçekleşen eski katılımcılık formu, gençler 
tarafindan tercih edilmemekte ve daha dinamik olan yeni katılım motivasyonları geliştirilmektedir. Bu yüzden aktif, proje bazlı veya kişinin kendisinin yönetmek istediği katılım türleri ve bu sebepten ötürü kısa süreli katılımlar süreklilik ve gönüllülük açısından başarısız kabul edilmemeli, çeşitlilik kabul edilmelidir. Sosyal katılımda bu değişimi destekleyecek yeniliklerle daha aktif katılıma ve sürdürülebilir katılımcılığa yol açılmalıdır. Mülakatlardan ve literatürden yola çıkılarak arkadaş faktörü kurumlar tarafindan motivasyon artırıcı bir etken olarak kullanılabilir. Gönüllü çalışmalara ve faaliyetlere katılanların genelde başka insanlara karşılık beklemeden yardımcı olma motivasyonu taşıdı̆̆ı yaygın bir görüştür. Hâlâ bu motivasyon devam ederken ilaveten gençler daha fazla proje odaklı, zaman ve içerik olarak daha spesifik beklenti içinde oldukları bir hâle dönüşmüştür. Hustinx (2001), gençlerin örgütlere olan bağlılıklarının düşük olduğunu, katılım konusunda titiz davrandıklarını ve gönüllülü̈kten kişisel faydalar beklediklerini belirtmektedir (Nihat Erdoğmuş, 2020). Değişen katılım formuyla gençlerin toplumsal faydadan bireysel faydaya yönelişi dikkate alınarak toplumsal ve bireysel fayda dengesini koruyabilecek ve bu sayede gençleri sosyal katılımdan uzaklaştırmayıp katılımdan beklentilerini karşılayarak onları sahada tutabilecek, iki fayda arasında dengeyi sağlayabilecek bir form oluşturulabilir.

Gençlerin değişen motivasyonlarını göz önünde bulundurursak sivil toplum kuruluşlarının gençleri, kurumlarına bağlamak yerine köprü görevi görmeleri, onlara eğitim ve işsizlik sorunlarına planlayacağı faaliyetler doğrultusunda destek olmaları, genç hedef kitlesini iyi takip etmeleri ve onların gelişimine katkıda bulunmaları gerekmektedir. Bu bağlamda STK'ların gençleri iyi tanımaları ve kariyer gelişimlerine katkı sağlayacak unsurları öne çıkaracak ihtiyaç temelli faaliyetleri planlamaları gençlere ulaşma ve iletişim kurmaları noktasında önemlidir.
Sosyal katılımın dönüşümü çerçevesinde liderlik mefhumuna bakacak olursak şurası açıktır ki geleneksel yöntemlerde ısrar eden birey ya da kurumlar günümüz insanına ve toplumuna hitap edememekte ya da bu konuda zorlanmakta ve başarısız olmaktadır. $\mathrm{Bu}$ problemi aşmak ve toplumsal fayda sağlamaya yönelik çalışmaları güçlendirmek için lider/liderlik uygulamalarında da birtakım değişiklikler yapma zorunluluğu doğmuştur. Öncelikli olarak lider ve katılımcılar arasında otoriter olmayan, geleneksel liderlikten uzak, eşitlikçi bir liderlik anlayışı benimsenmelidir; ne şekilde olursa olsun tahakküm kurmaktan kaçınılmalıdır. Katılımcıların kendilerini rahat bir şekilde ifade edebilecekleri ve yapılan çalışmalara kolayca motive olacakları özgür ve özgün ortamlar oluşturulmalıdır. Bununla birlikte katılımcıların kendi sınırlarını koymalarına izin verilmeli; yaşam tarzı, düşünce tarzı gibi özel alanlara müdahale edilmemelidir; katılımcıların birer özne oldukları unutulmamalıdır. Liderin özellikle kendi kişisel beklenti ve arzularını liderlik yaptığı grubun hedef ve amaçlarının önüne geçirmemesi de önemli bir nokta olarak karşımıza çıkmaktadır.

Gençler bağlamında sosyal katılımı zorlaştıran faktörlerden güven ve aile - arkadaş etkisi raporda zikredilmişti. Öte yandan, Dernekler Kanunu'nda yapılan değişiklikler ile STK'ların her an "faaliyetten menedilme" ve hatta "kapatılma” tehlikesiyle karşı karşıya olması gençlerin bu kuruluşlar ile olan bağına zarar vermektedir. Böylelikle devlet kurumları dışında kalan tüm sivil toplum kuruluşlarının devletle olan ilişsisinin her an değişebilme tehlikesi, gençlerin STK'lardan uzaklaşmasını hızlandırmaktadır. Gençler, kurumların daha şeffaf, tarafsız ve demokratik olmasını beklerken; devletin bu kurumlardaki çalışmalara karşı daha hassas, ön yargısız ve ancak zorunlu hâllerde tedbirleri sıklaştıran bir tutum içerisinde olmasını istemektedir. 
Gençlerin STK'larda aktif katılımcı olmasının önündeki bir diğer engelleyici faktör STK'ların ilişik olduğu ideolojik yahut dinî arka planlardır. STK'ların temel hareket noktasını din yahut ideolojik bir kaynaktan alması, gençlerin bu gibi kurumlara yaklaşmasını zorlaştırmaktadır. Sahadaki gençler bu STK'ların belirli bir ideolojik yahut dinî anlayışa dayanmalarını değil, bu kurumların bağlı oldukları dinî anlayışı yahut ideolojik görüşü dayatmacı tavırlarla sergilemelerini problemli görmektedir. Bu durumların yarattığı endişeler dolayısıyla gençlik organizasyonlarına katılım sağlamada çeşitli sorunlar yaşanmaktadır.

STK'ların karakteristik ögelerinin, bilhassa yapı özellikleri ve mensuplarının gençlerce birer imaj kıstası olarak görülmesi problematik hâle gelmiştir. Ebeveyn faktörü de düşünüldüğünde genç birey, "gelecekte bir sorun yaratabileceği" endişesiyle STK'lara karşı temkinli ve mesafeli bir tavır içerisindedir. Gençlerin kendilerini güven içinde hissettikleri ve gelecekte "terörist" yahut "zararlı oluşum” olarak nitelendirilmeyecek bir kurum arayışında oldukları görülmektedir. Bu noktada gençler ve devlet arasında karşılıklı güven ve iş birliğine dair çalışmalar yapılması gerekmektedir. Devlet kurumlarının sivil topluma alan bırakarak çeşitli sebeplerle buralardan burs alan, faaliyetlerinde gönüllü çalışan, görev alan ve buralarda akademik çalışmalar yapan gençleri zan altında bırakacak davranışlardan kaçınması gerekmektedir.

Gençlerin karşılaştığı bu mühim problemler etkili ve verimli bir şekilde çözülmeye muhtaçtır. Katılımcılardan gelen eleştiriler doğrultusunda STK'larda hâlihazırda görev alan gençlerin sahada karşılaştıkları sorunlara yönelik çözümler üretmekte zorlandığını görebilmek mümkündür. Değişen dünya ile farklılaşan istekler, çevresel faktörler, eğitim ve kişisel gelişimin farklı bir boyuta evrilmesi gibi konular teğet geçilmeyecek derecede önemli görülmektedir. Gençlerin “devlet vs. siyasal iktidar” ayrımında odaklandıkları nokta, kișisel ve kurumsal alana müdahalenin kimlerce ve ne amaçla yapıldığının tespitine yöneliktir. Bu tespit neticesinde genç bireylerin sivil topluma yönelik bakış açısı siyasal bir zemine kaymakta ve bu durum "devlet destekli STK'lar ve diğerleri” ayrımına yol açmaktadır. Dolayısıyla siyasal tercihleri farklı olan gençlerin gelecekte olumsuz bir durumla karşılaşmamak için mevcut siyasal iktidara yakın olan kurumlara katılım sağlamak istemediği gözlemlenmiştir.

Bununla beraber STK'ların misyon ve faaliyetlerinde daha şeffaf ve hesap verebilir bir yapıda olması, eleștiriye açık ve her kesimden insanları kucaklayan bir tutum sergilemesi gençlerin dikkatini çekmesi açısından önemlidir. Genç katılımcılar gönüllü olarak bir STK bünyesinde faaliyetlere katılmak için o STK'ların demokratik, eleştirel düşünceye yakın, sadece belirli bir dinî yahut ideolojik arka plana dayanmayan; evrensel ve çeşitli kimlikleri bir arada barındırabilen bir yönetim anlayışı beklemektedir. Çağımızın gerçeklerine paralel olarak yürütülmesi beklenen STK'ların yukarıda bahsedilen güvensizlik faktörleri ile mücadelede sahadaki gençlerin tecrübelerini ve beklentilerini dikkate alması önemli ölçüde faydalı olacaktır. Bu anlamda devletin kısıtladığı alanlarda insan hakları ve öz haklarının bir gereği olarak STK'ların direnç göstermesi, devlet değerlerine saygısızlık yahut var olan düzeni yıkmaya yönelik bir teşebbüs olarak algılanmamalıdır. Güvensizlik sorununun esas itibariyle sivil toplumun daralmasının hem nedeni hem de sonucu olduğunu söylemek mümkündür. Dolayısıyla güvensizlik faktörlerinin ve dijital katılım formunun doğurduğu sorunların gençlerin mevcut ihtiyaçlarının ve sosyal sermaye arayışlarının göz önüne alınarak çözülmesi gerekmektedir. 


\section{KAYNAKÇA}

Adler, Paul S. and Seok-Woo Kwon. 2002. "Social Capital: Prospects for a New Concept.” Academy of Management. The Academy of Management Review 27(1):17-40.

Aga, D. A., Noorderhaven, N., \& Vallejo, B. (2016). Transformational leadership and project success: The mediating role of team-building. International Journal of Project Management, 34(5), 806-818.

Aksulu, M. (2013). Yeni Toplumsal Hareketler: Türkiye'de Hayvan Hakları Savunuculuğu ve Sosyal Medya. Maltepe Üniversitesi, Sosyal Bilimler Enstitüsü. İstanbul.

Aktaş, M.,veAkçay,E.(2019).Dijital SavunuculukÖrneği Olarak “Özgecen YasasıI" Change.org İmza Kampanyası. Moment Dergi, 6 (2), ss. 305-336. Erişim adresi: https://dergipark.org.tr/ en/download/article-file/895792 (E.T: 17.04.2021).

Aktu, Y., ve Varol B. (2019). Ergenlerin Özçekim Bağımlılıyla Başa Çılkma Yolları. "International Asian Congress on Contemparay Scinces.

Alkan, M., Tekedere, H., \& Genç, Ö. (tarih yok). İnteraktif Bilgi İletişim Teknolojilerinin Uzaktan Eğitimdeki Uygulamaları.

Altan, S., \& Özpehlivan, M. (2019). Otokratik ve Katılımc1 Liderlik Anlayışının Örgütsel Vatandaşlık Davranışı Üzerine Etkisi: Sivil Toplum Kuruluşları Üzerine Bir Araştırma. The Journal Of Social Science, 3(5), 208-229.

Aslan, S. (2012). Demokrasi Bağlaminda Sosyal Sermaye ve Sivil Toplum İlişkisi. Mustafa Kemal Üniversitesi Sosyal Bilimler Enstitüsü Dergisi 9 (20), 45-58.

Bakan, İ., \& Büyükbeşe, T. (2010). Liderlik Türleri ve Güç Kaynaklarına İlişkin Mevcut-Gelecek Durum Karşılaştırması:
Eğitim Kurumu Yöneticilerinin Algılarına Dayalı Bir Alan Araştırması. 12(19), 73-84.

Bass, B. M. (1999). Two Decades of Research and Development in Transformational Leadership. European Journal of Work and Organizational Psychology, 8(1), 9-32.

Bostancı Ege, G. (2017). Kurgu Cağında Gerçekliğin Manipulasyonu, Popüler Kültür ve "Photoshop". Sosyoloji Dergisi, 36, ss.117-129.

Box Office Türkiye. (2021, Ocak 21). Türkiye ve dünya genelinde en çok abonesi olan dijital yayın platformları! 04 26, 2021 tarihinde Box Office Türkiye: https://boxofficeturkiye.com/ haber/turkiye-ve-dunya-genelinde-en-cok-abonesi-olan-dijitalyayin-platformlari-3084 adresinden alınd1.

Bunchapattanasakda, C., Wiriyakosol, S., \& Ya-anan, M. (2012). Leadership Roles on Employee Retaining Practice in Nongovernment Organizations (NGOs): The Case of Thailand. International Journal of Business \& Social Science, 3(8), 199203.

Buzan, B. (2015). İnsanlar, Devletler, Korku, ed. Emre Çıtak. İstanbul: Rölem Akademik Yayıncılık.

Cansoy, R., \& Turan, S. (2016). Gençlik Liderlik Özellikleri Ölçeği: Güvenirlik ve Geçerlik Çalışması. Türkiye Eğitim Dergisi, 19-39.

Chan, K. K. ve Misra, S. (1990). Characteristics of the Opinion Leader: A New Dimension, Journal of Advertising, 19(3), 53-60

Claridge, T. (2018). Functions of social capital - bonding, bridging,. Social Capital Research \& Training, Dunedin, New Zealand, 1-7.

Dijital Oyun Tarihi. (tarih yok). Nisan 26, 2021 tarihinde Timetoast: https:/www.timetoast.com/timelines/dijital-oyuntarihi adresinden alınd 1 
Duman, B. ve Alacahan, O. (2011). Sosyal Sermaye/Güven Boyutunda Etniklik. Gaziantep Üniversitesi Sosyal Bilimler Dergisi, 10 (1), 181-208

Dündar, M. K. (2006). Sosyal Sermaye ve Belirleyicileri Üzerine Ampirik Bir . Akdeniz İ.I..B.F. Dergisi (12), 61-78.

Eraslan, L. (2005). Liderlikte Post-Modern Bir Paradigma: Dönüsümcü Liderlik. Uluslararası İnsan Bilimleri Dergisi, 5(2), 1-32.

Erdogmus, N. \& Altınsoy, H.M. \& Sayın, Z. \& Aydemir Ö.F. (2020). Genç Gönüllülerin Motivasyonu STK'larda Devamlılığı Sağlayan Faktörler. Kurumsal Yönetim Akademisi Research report.

Eşki, H. (2009). Sosyal Sermaye-Önemi, Üretimi Ve ÖlçümüÜzerine Bir Alan Araştirmasi . T.c.selçuk Üniversitesi Sosyal Bilimler Enstitüsü İşletme An , 1-278.

Funk, R. (2020). Ben ve Biz - Postmodern İnsanın Psikanalizi. Yapı Kredi Yayınları.

Hustinx, L. (2001). Individualism and new styles of youth volunteering: An empirical exploration. Voluntary Action 3(2), 47-55.

Hustinx, L. (2001). Individualisation and new styles of youth volunteering: An empirical exploration. Voluntary Action, 3(2), 57-76.

Genç, Y.E. (2015). Üniversite Öğrencilerinin Sosyal Medya Kullanımı ve Bunun Satın Alma Davranışlarına Etkisi. İzmir Katip Celebi Üniversitesi Sosyal Bilimler Enstitüsü İşletme Anabilim Dalı. İzmir.

Goldsmith, R.E., and R.A. Clark. 2008. An analysis of factors affecting fashion opinion leadership and fashion opinion seeking. Journal of Fashion Marketing and Management 12, no. 3: 308-22. doi:10.1108/13612020810889272.

GÖK, M. (2015). Türkiye'de Sivil Toplum Kuruluşlari Ve Sosyal Serma Sosyoloji Konferansları, 655-683Gaming in Turkey. (2019). Türkye Oyun Sektörü 2019.

Gölcü, A, Balcı, Ş, Arsal Gölcü, A. (2019). Sosyal Medya Kullanımı ile Kendini Gizleme ve Yasam Doyumu Arasında Bir Bağlantı Var M1?, Afyon Kocatepe Üniversitesi Sosyal Bilimler Dergisi, 21 (1), 173-190.

Görgülü, B. (2018). Gençlerin Siyasi Katılımında Sosyal Medyanın Rolü. Selçuk Üniversitesi Sosyal Bilimler Enstitüsü, Yayınlanmamış Yüksek Lisans Tezi. İzmir.

Guo, C. ve Saxton, G. D. (2014). Tweeting Social Change: How Social Media Are Changing Nonprofit Advocacy. Nonprofit and Voluntary Sector Quarterly, 43 (1), ss. 57-79.

Gümüs, T., (2014). Demokrasilerde Sivil Toplum ve DevletSivil Toplum İlişkisinde Karşılaşılabilecek Sorunlar, Gazi Üniversitesi Hukuk Fakültesi Dergisi, 18(3-4): 529-572.

Gül Ünlü, D, Zeybek, B. (2020). Sosyal Medya Fenomeni ve Marka İşbirliği: İşbirliği Paylaşımlarına İlişkin Instagram Kullanıcı Yorumları Üzerinden Bir Değerlendirme. AJIT-e: Bilişim Teknolojileri Online Dergisi, 11 (41), 72-95. DOI: 10.5824/ajite.2020.02.004.x

Gür, E. ve Bahçeci D. (2014). Karşıllaştırmalı Bir Analiz: Avrupa'da Gençlerin Katılımı ve Gençlik Politikası, İstanbul Bilgi Üniversitesi Şebeke Gençlerin Katılımı Projesi Kitapları No: 10, İstanbul: İstanbul Bilgi Üniversitesi Yayınlar1.

Internet Stats and Facebook Usage in Europe November 2015 Statistics. https://www.internetworldstats.com/stats4.htm (E.T: 17.04.2021). 
İgit, A. (2020). Dijital Oyunlarda Empatik İletişim. Nobel Akademik Yayıncılık.

Justwatch. (tarih yok). Nisan 26, 2021 tarihinde Justwatch: https://www.justwatch.com/adresinden alındı

Juul, J. (2003). Half-Real: Video Games Between Real Rules and Fictional Worlds Jesper Juul. Jaskyte, K. (2004). Transformational leadership, organizational culture, and innovativeness in nonprofit organizations. Nonprofit Management and Leadership, 15(2), 153-168.

Kantos, Z. E. (2011). Örgüt Metaforlarında Liderlik: Kavramsal Bir Çözümleme. Eğitim Bilimleri Araştırmaları Dergisi, 135158.

Karakoç, E. ve Taydaş, O. (2013). Bir Serbest Zaman Etkinliği Olarak Üniversite Öğrencilerinin İnternet Kullanımı ve Yalnızlık Arasındaki İlişki: Cumhuriyet Üniversitesi Örneği. Selçuk İletişim, 7, (4), ss. 33-45.

Kılınç, E. (2019). Sivil Toplum Kuruluşlarında Liderlik. Bingöl Üniversitesi Sosyal Bilimler Enstitüsü Dergisi, 9(18), 10911112. https://doi.org/10.29029/busbed.561038.

Köse, H. (2008). İnternette "Açık” ve Demokratik Yayıncılık: "Sanal Ortam Günlükleri” ve Wiki'ler. Marmara İletişim Dergisi, 13 (13), ss.83-93.

Koo, J., Kim, K., \& Kim, J. (2017). The Relationship between Transformational Leadership of Environmental NGO Leader and Trust and Organizational Commitment. Global Business \& Finance Review.

Manning, S. (2005). Young Leaders: Growing Through Mentoring. Gifted Child Today. 
Nissenbaum, H. (1999). The meaning of anonymity in aninformation age. The Information Society, 15, 141-144.

Nolto. (tarih yok). 2020 Yılı Video Konferans İstatistikleri. Nisan 26, 2021 tarihinde Nolto: https://www.nolto.com/ telekomunikasyon/2020-yili-video-konferans-istatistikleri/ adresinden alındı.

Oyman, M, Akınc1, S. (2019). Sosyal Medya Etkileyicileri Olarak Vloggerlar: Z Kuşağı Üzerinde Para-Sosyal İlişki, Satın Alma Niyeti Oluşturma ve Youtube Davranışları Açısından Vloggerların İncelenmesi. Akdeniz Üniversitesi İletişim Fakültesi Dergisi, (32), 441-464. DOI: 10.31123/akil.620050

Özkan, A., \& Hira, İ. (2012). Dijital Medya ve Sosyalleşme: 6-12 Yaş Çocukların Sosyallesine Dair Ebeveyn Görüşleri. Kesit Akademi Dergisi , 245-270.

Öztürk, A. T., \& Emli, İ. (2017). Liderlik Olgusu Ve Katılımc1 Liderlik Özellikleri Üzerine Nitel Araştırma:"Bir Sivil Toplum Kuruluşunda Uygulama Örneği”. Üçüncü Sektör Sosyal Ekonomi Dergisi Ekonomi Dergisi, 52(3), 97-126. https://doi. org/10.15659/3.sektor-sosyal-ekonomi.17.12.723

Patulny, R. V. (2007). Exploring the social capital grid:bonding, bridging, qualitative,. International Journal of Sociology and, 32-51.

Paxton, Pamela. 2002. "Social Capital and Democracy: An Interdependent Relationship." American Sociological Review 67(2):254-77

Pessi, Anne. (2004). The Octagon Model of Volunteer Motivation: Results of a Phenomenological Analysis. Voluntas. 15. 21-46. 10.1023/B:VOLU.0000023632.89728.ff.

Rehberg, Walter. (2005). Altruistic Individualists: Motivations for International Volunteering Among Young Adults in
Switzerland. Voluntas. 16. 109-122. 10.1007/s11266-005-5693-5. Resmî Gazete, Dernekler Kanunu. 6 Nisan 2021 tarihinde https://www.mevzuat.gov.tr/MevzuatMetin/1.5.5253.pdf sitesi adresinden alındı.

Sarıtaş, A. (2019). Sosyal Medya Reklamlarında Fenomen Kullanımı ve Reklam İzleme Tercihi. The Journal of International Scientific Researches, ISR 2018, 3 (4) , 62-74 . DOI: 10.23834 /isrjournal.473169.

Saxton, G. D., Niyirora, J., Guo, C., ve Waters, R. (2018). \#AdvocatingForChange: The Strategic Use of Hashtags in Social Media Advocacy. "Advances in Social Work" 16 (1), ss. 154-169.Şahin, M., Şahin, Gökçe (2016). Geleneksel Medyanın Yeni Rakibi: Yeni Medya ve Canlı Yayınlar. Hakemli Akademik E-Dergi , 50-63.

Senft, T. M. (2013). Microcelebrity and the branded self. In J. Hartley, J. Burgess, \& A. Bruns (Eds.), A Companion to New Media Dynamics (pp. 346-354). Blackwell Publishing.

Safak Baykal, S. G. (2016). Sosyal Sermaye ve Bireyler Arası Güven İlişkisinin Sosyal Ağ Analizi ile İncelenmesi. İş ve İnsan Dergisi 3(2), 77-91.

Tam, M.S (2020). Sosyal Medya Kullanım Motivasyonlarının, Sosyal Medya Fenomenlerinin Kanaat Önderliği Rolü Üzerine Etkisi. (Doktora Tezi, İstanbul Üniversitesi)

Taylor, C. (2001). Sources of The Self - The Making of Modern Identity. Harvard University Press.

Tengilimoğlu, D. (2005). Kamu ve Özel Sektör Örgütlerinde Liderlik Davranışı Özelliklerinin Belirlenmesine Yönelik Bir Alan Çalişmasi. Elektronik Sosyal Bilimler Dergisi, 4(14), 1-16. Tutkun Ünal, A. (2020). Sosyal Medya, Etkileri-BağımlılığıÖlçülmesi. İstanbul: Der Kitabevi. 
TÜSEV. (2011). Türkiye'de Sivil Toplum: Bir Dönüm Noktası CIVICUS Uluslararası Sivil Toplum Endeksi Projesi (STEP) Türkiye Ülke Raporu II, İstanbul: TÜSEV Yayınları. 56: 43-66.

Van L. J. ve Van A, P. (2010). Internet and Social Movement Action Repertoires: Opportunities and Limitations. Information, Communication \& Society, 13 (8), ss. 1146-1171.

Vatandaş, C., Can B., Yıldırım, H., Mahitapoğlu, M., (2016). Türkiye'de Gençliğin Güven Bunalımı, İstanbul: Sekam Yayınları.

Walseth, K. (2008). Bridging and bonding social capital in. Sport, Education and Society, 1-18.

Weimann, G., 1994 The influentials: People Who Influence People, New York, State University of New York Press.

Woolcock, Geoffrey. 2002. "Social Capital and Community Development: Fad, Friend or Foe?” in Queensland Local Government Community Services Association Annual Conference. Rockhampton.

Yavaşçalı, A. H., ve Uğurcan Y. Z. C. (2019). Neden Kullanıcılar Twitch TV Üzerinde Bağıs Yapar? Twitch TV Kullanıcıları Üzerinde Ampirik Bir Çalışma. Gümüşhane Üniversitesi İletişim Fakültesi Elektronik Dergisi, 7 (2), ss. 646-678

Yavuz, S.(2012).İ̧̧letmelerdeSosyalSermayenin Ölçümlenmesi Ve Raporlanmasina Yönelik Bir Araştirma. T.c.balikesir Üniversitesi Sosyal Bilimler Enstitüsü İşletme An, 1-117.

Yentürk, N. v. (2006). İstanbul Gençliği: STK üyeliği bir fark yaratıyor mu? İstanbul: İstanbul Bilgi Üniversitesi STK Eğitim ve Araştırma Birimi.

Yılmaz, A., \& Akdeniz, B. (2020). Sivil Toplum Kuruluşlarında Başarıya Götüren Yönetim ve Liderlik Özelliklerine İlișkin Bir İnceleme. Türk İdare Dergisi.
Yılmaz, E., \& Çağıltay, K. (2004). Elektronik Oyunlar ve Türkiye. TDB 21. Ulusal Bilişim Kurultayı.

Yılmaz, Ş. K. (2015). Sosyal Sermaye Bağlamında Kütüphane Kurumu. Bilgİ Dünyası 16 (2), 180-203.

Ying, M. (2012). Sosyal Medya Platformları Üzerinden Pazarlama ve Bu Mecrayı Etkin Kullanan Sektörler. Kadir Has Üniversitesi Sosyal Bilimler Enstitüsü İşletme Anabilim Dalı, İstanbul. Yayınlanmamış Yüksek Lisans Tezi). İstanbul. 


\section{Notlar:}

Bir Literatür

Değerlendirmes 
Notlar: 


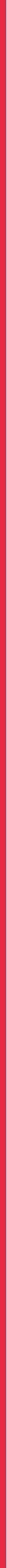

